University of San Diego

Digital USD

2003-05-13

\title{
Goddesses in the Union: A Qualitative Study of Women in Leadership Positions in College and University Union Settings
}

Susan H. Payment EdD

University of San Diego

Follow this and additional works at: https://digital.sandiego.edu/dissertations

Part of the Leadership Studies Commons

\section{Digital USD Citation}

Payment, Susan H. EdD, "Goddesses in the Union: A Qualitative Study of Women in Leadership Positions in College and University Union Settings" (2003). Dissertations. 715.

https://digital.sandiego.edu/dissertations/715

This Dissertation: Open Access is brought to you for free and open access by the Theses and Dissertations at Digital USD. It has been accepted for inclusion in Dissertations by an authorized administrator of Digital USD. For more information, please contact digital@sandiego.edu. 


\title{
GODDESSES IN THE UNION: \\ A QUALITATIVE STUDY OF WOMEN IN LEADERSHIP \\ POSITIONS IN COLLEGE AND UNIVERSITY UNION SETTINGS
}

By

\author{
Susan H. Payment \\ A dissertation submitted in partial fulfillment \\ of the requirements for the degree of \\ Doctor of Education \\ University of San Diego
}

May 13, 2003

Dissertation Committee

Dr. Robert Donmoyer, Ph.D., Chair

Dr. Terri Monroe, RSCJ, Ed.D.

Dr. Kim Braun Padulo, Ed.D. 
(C) Copyright 2003

By

Susan H. Payment

All Rights Reserved. 


\section{ABSTRACT}

\section{GODDESSES IN THE UNION: A QUALITATIVE STUDY OF WOMEN IN LEADERSHIP}

POSITIONS IN COLLEGE AND UNIVERSITY UNION SETTINGS

The student union facilities found on the majority of college and university campuses within the United States serve a variety of functions. Commonly referred to as the "living room" of the campus community, student unions provide space for cocurricular educational experiences, study and reflection, organizational meetings/business, retail operations, dining and entertainment.

The field of university union management attracts individuals that enjoy working in complex, high-energy environments where learning and student development are encouraged. Despite the overwhelming presence of women in today's workforce, the realm of university union management remains dominated by men. A "glass ceiling" appears to exist in this field.

The overarching purpose of this study was to better understand factors that have lead to the scarcity of women in positions of executive director or director in university union settings. This study did this by focusing upon the perceptions and experiences of nine women who currently hold or have held the title of director or executive director of a college or university union facility.

A qualitative case study/cross case analysis design was utilized for this project. Following the collection of data through the use of a written participant profile and oral interviews with each of the respondents, case studies were constructed and presented in a narrative form to allow the individual personalities of the participants to emerge. The use of cross case analysis grouped the data into organized themes and provided a sense of the patterns that cut across individual and particular contexts, resulting in the emergence of trends that were significant to understanding this particular population. 
The respondents in the study did not perceive gender playing a significant role in obtaining a union director position, though a careful analysis of the findings suggests the hypothesis that gender may have had more of an indirect effect than respondents perceived. Some respondents did allude to encountering some degree of gender discrimination once hired to fill a union director position, but it appeared as if the nine respondents in the study were successful in overcoming and/or managing this discrimination. All found their jobs tremendously satisfying and believed they were highly effective in executing the complex set of tasks that must be performed as union directors. All respondents also indicated that they had developed ways to retain some semblance of a private life in addition to their careers. Some respondents' strategies appeared to be more successful than others' strategies, and it may be significant that a majority of the respondents were not married and had no children. The intrusion on private lives factor, in other words, may be a partial explanation for the appearance of a glass ceiling phenomenon in the world of the union directorship. 


\section{DEDICATION}

In Memory of John D. Hosking 


\section{ACKNOWLEDGEMENTS}

The completion of this study would have been impossible without the assistance and support of a multitude of individuals. While I hope to thank them all, like the best Academy Award acceptance speeches, I am doomed to leave someone out.

First, my sincere thanks are extended to the members of my committee; Dr. Robert Donmoyer, Dr. Terri Monroe, RSCJ and Dr. Kimberly Braun Padulo. Their thoughtful suggestions and critical feedback allowed me to focus on my goal of completing my program in a timely manner. Thank you for your insight and encouragement.

My colleagues and students at the University of San Diego were patient and understanding throughout my doctoral career. Thank you for allowing me to miss programs, meetings or events to attend class, write papers and conduct research.

My husband, Shawn, was more than generous with providing me the time to "work on my little paper." Gizmo and Perry were always there to provide comfort during a break in my scribbling and never failed to make me smile.

When I left home to begin my undergraduate career at the University of Michigan, my father, John D. Hosking, noted that he didn't care if I received my bachelor's degree or not. He was simply pleased that I had taken a step towards independence in my decision to leave home and enjoy living on campus. And while he is not able to celebrate this accomplishment with me in person, I hope that he is able to know that I "went all the way."

The concern and perpetual worry of my mother, Celia Hosking, is also appreciated. Although she continues to urge me to "get a real job," I need to reassure her that the rewards and satisfaction of working with students far outweighs the demands my work may place on my time and energy.

Finally mere words cannot begin to express my gratitude to the goddesses that willingly participated in this project. My respect for these women, the work that they do and the students and staff they inspire has been heightened through our interaction. May their work continue to encourage and enlighten students and young professionals for generations to come. 


\section{TABLE OF CONTENTS}

1. Chapter One: Overview of the Study ............................. 1

Background to the Study ......................................... 1

Statement of the Problem..................................... 3

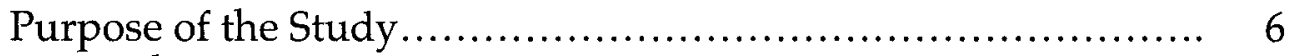

Research Questions............................................. 7

Methodology .................................................. 8

Delimitations and Limitations of the Study ...................... 8

Significance of the Study ....................................... 11

2. Chapter Two: Review of the Literature........................... 12

Women in Higher Education Administration..................... 12

University Union Management................................... 15

Leadership/Management Styles.................................. 19

Women's History ................................................. 21

Education, Training and Career Development...................... 29

Balance.............................................................. 32

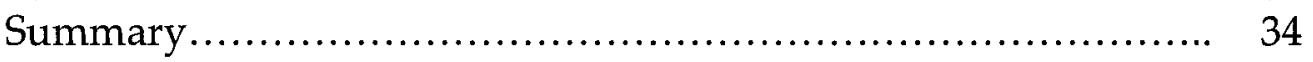

3. Chapter Three: Methodology ................................. 37

Reasons for Using Qualitative Research in this Study ............... 38

Case Study Approach..................................... 39

Cross Case Analysis......................................... 39

Committee on the Protection of Human Subjects................... 40

Data Collection.................................................. 41

Participant Selection.................................. 41

Participant Profile/Questionnaire........................ 43

Interview Guide.......................................... 43

Interviews................................................ 44

Researcher Role............................................ 45

Data Analysis................................................... 46

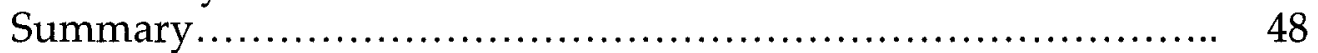

4. Chapter Four: Findings......................................... 49

Case Study One: Ann .......................................... 49

Case Study Two: Barbara...................................... 55

Case Study Three: Carol............................................. 59

Case Study Four: Donna...................................... 63

Case Study Five: Ellen.................................................. 69

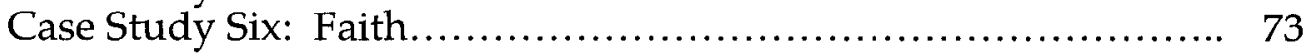

Case Study Seven: Gwen.......................................... 78

Case Study Eight: Helen...................................... 80

Case Study Nine: Iris........................................ 84

Cross Case Analysis............................................. 91

Effect of Gender on the Ability to Obtain a Directorship.... 92

Impact of Gender on the Ability to Succeed in the Field..... 99

Effect of Career on Personal Life............................ 105 
Summary $\ldots \ldots \ldots \ldots \ldots \ldots \ldots \ldots \ldots \ldots \ldots \ldots \ldots \ldots \ldots \ldots \ldots \ldots \ldots, 107$

5. Chapter Five: Discussion................................... 109

The Effect of Gender on the Ability to Obtain a Directorship...... 109

The Impact of Gender on the Ability to Succeed in the Field....... 112

Impact on Personal Life...................................... 114

Suggestions for Future Research............................. 117

Recommendations............................................ 119

Reflections on the Research Process.......................... 120

Conclusion.................................................. 121

References....................................................... 123

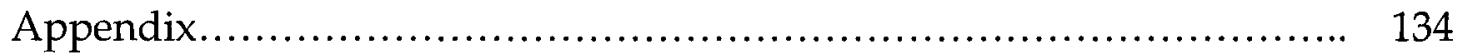


CONTENTS OF APPENDICES

\section{Appendix}

A, Informed Consent Form.................................... 135

B Participant Profile...................................... 136

C, Interview Guide......................................... 138 


\section{CHAPTER ONE \\ OVERVIEW OF THE STUDY}

\section{Background to the Study}

The student union facilities found on the majority of college and university campuses within the United States serve a variety of functions. Commonly referred to as the "living room" of the campus community (Fagan, 1996), union facilities provide space for co-curricular educational opportunities (workshops, films, speakers, etc.), study and reflection, organizational meetings/business, retail operations (bookstore, copy center), dining and entertainment. In addition to serving as a source of comfort and communitybuilding, student unions may also be viewed as living laboratories, full of human beings of different ethnicities, origins, socioeconomic backgrounds, etc. They allow students, faculty and staff members to interact in an informal setting and encourage learning outside of the more traditional classroom setting.

The origins of the college or university union can be traced to the debate societies found in fifth century Greece (Swanka, 1997, p. 15). These societies became the model for the debating societies that emerged at Cambridge and Oxford in the early nineteenth century. The Cambridge Union, for example, was established to provide young men with a forum for free and open discussion of 
"urgent political questions" (Butts, 1971, p. 3). It also served as a proving ground for future statesmen and members of Parliament as they were able to gain valuable public speaking experience through their membership.

The union created at Oxford held a similar purpose to the organization at Cambridge. In addition to its primary function as a debating society, however, Butts (1971) notes that the society at Oxford was also viewed as, "a large literary club, where every opportunity is afforded to those desirous of improving their mind" (p. 5). Oxford's debating society also offered a glimpse of what university unions would look like in the future since Butts also notes that an extensive library and meeting space was available to its membership for both academic research and recreational pleasure ( p. 5).

Debating societies began to appear on American campuses with the founding of the Harvard Union in 1832 (Swanka, p. 15). While the original concept of university unions as debating societies remained, the vision was gradually expanded to include facilities for other student clubs, dining facilities and meeting and performance spaces. The term "university union" eventually came to be associated with a building or facility, rather than a group or organization.

In 1896, Houston Hall opened its doors on the University of Pennsylvania campus and is recognized as the first university union established in the United States. The facility featured student offices, an auditorium, dining rooms and lounges and served as a model for similar structures that began to appear at other campuses throughout the country (Yates, 1992). Higher education institutions included in the Big Ten Conference (e.g., Michigan, Indiana, Iowa and Wisconsin) built unions as war memorials to those lost in World War I. 
The scope and purpose of programs and resources offered by college unions continued to evolve throughout the twentieth century. In the 1920s, union events included lectures, art exhibitions, recreational tournaments and dances (Carlson, 1989). During World War II, unions provided meals to military units, sponsored Red Cross training programs and served as a social outlet for military cadets (Ketter, 1989).

The end of World War II and the introduction of the G. I. Bill resulted in an enrollment boom and a need for additional facilities, programs and services at many institutions. This educational explosion resulted in the construction of a multitude of college unions on both four-year and two-year campuses. By 1949, there were approximately 150 unions on campuses throughout the United States. Within two decades, this number had ballooned to nearly 600 (Butts, p. 93). Swanka (1997) notes that the majority of college unions currently in operation were built between 1950 and 1970 and are indicative of the significant growth in the union movement during this period.

\section{Statement of the Problem}

The literature that details the history and philosophy of the university union movement is lacking in one prominent area: the presence of women. From their earliest inceptions at Cambridge and Oxford, union membership was restricted solely to men (primarily because institutional enrollment was limited to males). This pattern was repeated as unions were established in the United States, even on co-educational campuses. 
For example, use of the facility currently known as the Old Union at Stanford University was restricted to men in the early 1900s. A separate "clubhouse" was constructed for female students (http://www.stanford.edu/home/welcome/campus/oldunion.html). The Indiana Union (on the Indiana University campus) was originally established as "the men's union" in 1909. It wasn't until 1952 (after a year of "lively debate") that female students were admitted to the Union Board and allowed to actively participate in the governance of the union and its activities (http://wwww.imu.indiana.edu/about the imu/history.html). At the University of Michigan, the Michigan Union was formed in 1904 as an "all inclusive organization, focused on providing feelings of unity for men on campus." Women were able to enter the union building only through a specified entrance and when accompanied by a male escort. A separate facility (the Michigan League) was built to serve as the social, cultural and recreational center for female students. Women were denied equal access to the Michigan Union until 1968 (http://www.umich.edu/ munion/).

The evolution of women in professional roles in university union settings followed a similar path. As union programs and services diversified during the 1930s and 1940s, women began to serve as social directors and helped to plan activities (Ketter, 1989). When male staff members left their positions to join the military during World War II, women entered various staff positions, including union directorships. This progress proved to be temporary, however, as many women were forced to resign their positions when men returned after the war (Smith, 1989). 
Since the 1950s, women have slowly begun to achieve union directorships at facilities on campuses throughout the country. Many entered the field as program coordinators or directors of student activities and gradually assumed additional responsibilities that were associated with the union management (Swanka, 1997). While the college and university union philosophy today advocates the holistic development of all its student inhabitants regardless of gender, an apparent contradiction is evident in the limited number of female staff members who hold the title of director or executive director of union facilities in the United States.

The annual salary survey conducted by the Association of College Unions International (ACUI) for the year 1997-1998 revealed that women held only 29.4 percent of union directorships or executive directorships and that male union directors earned up to $19.1 \%$ more than their female counterparts. The study also noted that the highest representations of women within a college or university union setting were found in positions that were more clerical in nature, including scheduling and reservations managers, information/ticket center managers and promotions or marketing managers (ACUI, 1998).

The field of university union management attracts individuals who enjoy working in complex, high-energy environments where learning and student development are encouraged. Union directors face crises on a daily basis and typically work more than forty hours per week (including evenings and weekends). Despite the overwhelming presence of women in today's workforce, the realm of university union management remains dominated by men. The data generated by the annual salary survey administered by ACUI reinforces the 
existence of a "glass ceiling" in the field. There is a need to better understand the factors that inhibit and facilitate women serving as directors of university unions.

Unfortunately, previous research related to women in the field of university union management has been extremely limited (Swanka, 1998; Swanka, 1997; Mercer, 1990). Instead, a large number of studies have examined the career paths of female senior student affairs officers (SSAO's) which may or may not have included time spent as a union director (House, 2001). Additional studies have focused on issues such as balancing a career and a personal life, mentoring and professional development for female student affairs professionals (Blackhurst, 2000; Nobbe \& Manning, 1997; Padulo, 2001; Twale \& Jelinek, 1996; Wilson, 2000). Although these studies have proved useful, a definitive need to systematically study the pioneering women who have successfully held directorship positions at college or university unions within the United States is evident.

\section{Purpose of the Study}

The overarching purpose of this study was to better understand factors that have led to the scarcity of women in positions of executive director or director in university union settings and factors that might contribute to changing this situation. This study did this by focusing upon women who have been successful in what traditionally has been a man's world. Specifically, the study examined the perceptions and experiences of nine women who currently hold or have held the title of director or executive director of a college or university union facility. 
Particular attention was paid to the participants' educational backgrounds, personal lives, career goals and aspirations and the perceived impact gender has played on their ability to succeed in the field of university union management. This study did not attempt to define a "typical" female university union director, primarily due to the individuality of each union and the inconsistency in the flexible nature of the activities and events that occur at each site. Instead, it considered the significance of apparently salient factors in the unique context in which female union directors worked.

Webster's New Collegiate Dictionary (1975) defines a goddess as "a woman who is widely admired or imitated, especially for her beauty." This definition may be easily applied to all of the subjects included in this study. Due to their leadership, intellect and service to their respective campus communities, they have earned the admiration of both colleagues and students and their "beauty" transcends mere physical attributes.

\section{$\underline{\text { Research Questions }}$}

The following questions were used to guide this study:

a.) According to the female university union directors' perceptions, what effect, if any, has their gender had on their ability to obtain a directorship position within the field of university union management?

b.) According to the female union directors' perceptions, what effect, if any, has gender played on their ability to succeed within the field 
of university union management following their promotion to a directorship position?

c.) According to the female union directors' perceptions, what effect, if any, has their decision to pursue a career in university union management had on their personal lives?

\section{Methodology}

A qualitative research orientation was used to guide this study. Data were obtained through the use of a written participant profile and oral interviews with each of the nine participants included in the sample. Individual case studies were constructed in order to understand the personal experiences of each of the respondents and gain an in-depth view of their roles as union directors (Rubin \& Rubin, 1995) and, more specifically, their perceptions of how gender has impacted their acquiring their positions, their ability to succeed in their positions, and the impact their positions have had on their personal lives. A cross-case analysis was also completed in order to examine the data in aggregate form and to begin to look for patterns across contexts related to the three research questions articulated above.

\section{Delimitations and Limitations of the Study}

\section{Delimitations}

This study focuses upon the experiences of a small number of respondents from similarly sized institutions in selected regions of the country in which there 
is a relatively common philosophical orientation: support the university community and the holistic development of students.

\section{Limitations}

The membership directory of the Association of College Unions International (ACUI, 1999) served as the sole source for the identification of possible participants for this study. Additional professional organizations related to higher education administration (such as NASPA, ACPA and NACA) were not considered due to the wide variety of positions represented by their members. This decision, however, may have resulted in the exclusion of different sorts of respondents and as a consequence, limited the range of insights this study might have provided.

The sample also included only women that had achieved success in the college union field (i.e., had obtained a director or executive director position and for the majority of the sample, held the same position for two or more years). Women that had considered union management as a viable career option and had failed to secure a directorship were not considered. While the stories of this second unsuccessful group would undoubtedly have been significant in their own right, the focus of this project was limited to women that had met the criteria for success that served as parameters for this study and who agreed to participate in the project. Nine of eleven women identified as possible participants through sampling strategies detailed in Chapter 3 agreed to serve as respondents in this study.

All of the women included in the study were employed at fairly large, public, four-year institutions (averaging more than 10,000 students). While unintentional, this occurrence may have limited the diversity of their experiences 
and also impacted the overall effectiveness of the cross-case analysis approach that was utilized. Efforts made to identify additional subjects that were employed at two-year or small/private institutions in order to diversify the sample and include data from individuals associated with a greater variety of sites proved unsuccessful. The significance of the "clustering" of participants at institutions that were similar in size and scope is addressed in the findings section of this document.

The use of oral interviews as the primary source of raw data may have limited the depth and breadth of the responses provided by participants. Their perspectives could have proved to be overly subjective or introspective, thereby diminishing the possibility that common themes or sub-topics would emerge. The awareness of this potential allowed for an increased sensitivity to how the values, attitudes and understandings of both the researcher and the participants evolved throughout the duration of study (Glesne, 1990).

The role of the researcher posed several potential liabilities to the internal validity and objectivity of the study. While the researcher's experience in the field of student activities allowed for increased access to the participants and sites and the development of trust relationships with each subject, it also presented the opportunity for increased levels of subjectivity to influence both the data collection and data analysis phases of the project (Peshkin, 1988). This probability was diminished through the purposeful selection of subjects from a group in which the researcher is not a member, and with whom the researcher had limited prior contact. While I may work in a university union setting, I am not a union director. 
Finally, the external validity - as traditionally defined - is problematic due to the limited number of respondents who were studied. Rather than thinking of external validity or generalizability in traditional ways, however, this study conceptualized generalizability in the psychological sense described in Chapter 3. In this respect, at least, the study has more in common with such traditional humanities disciplines as anthropology and history than with traditional social science.

\section{Significance of the Study}

This study is helpful in understanding how some women have successfully negotiated terrain in which women in general have been less than successful. Their perceptions of barriers - or lack of barriers - in attaining their professional positions, of factors that contributed - and interfered with - their success on the job, and how they meshed professional responsibilities with aspects of their personal lives should provide valuable insights for both scholars in the field and important humanistic understanding for other practitioners. 


\section{CHAPTER TWO \\ REVIEW OF THE LITERATURE}

The initial literature review entailed examining work in five areas: women in higher education administration, university union management, leadership/management styles, mentoring and role modeling, and women's history. Following the completion of the pilot study in Spring 2001, the topics were expanded to include (a.) training, education and career development opportunities available to university union directors and (b.) the concept of "balance" for women in the American workforce.

\section{Women in Higher Education Administration}

The majority of the literature related to women in the field of higher education administration was produced during the past three decades (House, 2001). Some of the topics addressed in studies conducted during this time period include career satisfaction among female student affairs officers, perceptions of sex discrimination, reasons women leave the field and possible influences affecting women's attainment of desirable positions. While the bulk of materials related to this topic do not specifically identify female union directors as research subjects, some of the studies did include union directors in their samples. In addition, the experiences of women in higher education administration appear to 
have a number of characteristics (regardless of position or title), that are similar to the experiences of the women interviewed for this study (see for example, Blackhurst, Brandt \& Kalinowski, 1998; Blackhurst, 2000a; Blackhurst, 2000b; Burns, 1982; Earwood-Smith, Jordan-Cox, Hudson \& Smith, 1990; Nobbe \& Manning, 1997; Twale \& Jelinek, 1996; and Wilson, 2000). These characteristics include varying levels of career satisfaction, difficulty identifying female mentors and/or establishing collegial relationships with co-workers of the opposite sex, inequities in pay and issues related to balancing professional and personal roles.

Nidiffer and Bashaw's (2001) collection of essays entitled, Women Administrators in Higher Education provided both historical and contemporary perspectives of female administrators in higher education. The authors appeared hopeful about the future even as they dispelled past problems: "As role models, the leadership of today's women undoubtedly serves as inspiration to untold numbers of other women on campus" (p. 5). Unfortunately, the chapter written by Jones and Komives noted that the presence of women has increased in nearly every student affairs category except in positions reflecting "a broad span of leadership, supervision and budget authority (e.g., residence life, student union, admissions and senior student affairs officers), with student union directorships increasing only $7 \%$ between 1980 and $1985^{\prime \prime}$ (p. 236).

Holliday and Marshall (1987) described the climate for women in higher education administration as "chilly" and noted that a bottleneck of women in middle management positions prevented advancement to higher levels. They also observed that the high visibility of the few women in vice president, chancellor or presidential roles created the false perception that women held a significant number of these positions, when in fact, they do not (p. 96). 
Blackhurst, Brandt and Kalinowski (1998) found that the organizational commitment and job satisfaction of female student affairs officers were dependent upon such career development variables as position titles, educational level, the number of years subjects had held their current positions as well as the number of years they had been in the field. A subsequent study by Blackhurst (2000) attempted to determine if any significant changes had occurred in the areas of gender equity and attrition rates of women in student affairs positions during the previous decade. Although the findings noted an increase in the level of career satisfaction for participants, the results were off-set by the responses given by women of color included in the sample who typically occupied mid-level positions and perceived moderate to high levels of sex discrimination. Examples included inequities in pay, being asked to work additional or longer hours than male colleagues, being provided less support and being assigned less visible or rewarding tasks.

Journal articles have also identified potential "stepping stones" that women could consider to help ensure their success in the field of higher education administration. Lunford's (1984) study of 147 male and female student affairs officers found that a combination of academic training and practical experience helped them to achieve their current positions. EarwoodSmith, Jordan-Cox, Hudson and Smith (1990) recommended that females in the field should obtain a terminal degree, gain expertise in a particular area and then become a generalist, build a network through involvement in professional organizations and develop outside interests to help promote balance between their work and personal lives. This path is similar to the timeline offered by a number of the female union directors included in this study, who encourage 
young women to finish their education, establish a professional network, become involved in their surrounding communities, identify hobbies or interests and make time for family and friends.

\section{University Union Management}

The growth and development of the university union movement in the United States has been documented by both Butts (1973) and Berry (1984). Each author examined the gradual transformation of student unions from male debating societies to multidimensional facilities that offer spaces for study, recreation, dining and co-curricular activities. These works demonstrated the fundamental shift of college and university unions from all-male organizations to integral components of campus communities that foster the holistic development of students and professionals and promote learning outside of the classroom (Fagan, 1989; Levitan \& Osteen, 1992).

Records and publications distributed by the Association of College Unions International (ACUI) proved to be invaluable to this study. Salary surveys conducted over a twenty-year time period (Clay \& McMillan, 1974; Delahunty, 1986; ACUI, 1994) documented the limited increase in the number of women in union directorships and the notable difference in pay between male and female union directors.

Articles featured in the ACUI Bulletin further solidified the definitive presence that student unions continue to hold on college campuses and the significant roles that unions and their staff members play at their respective institutions. A survey administered in September 1994 (Shindell \& Pirelli, 1995) 
measured the perceptions of 114 university presidents and/or chancellors and their understanding of their college union's mission or function. Sixty percent of the respondents felt that they were aware of their union's mission statement prior to receiving the survey and 90\% thought their union's mission statement supported their institution's overall mission in an appropriate manner.

Possibly the most significant finding of the survey was this: data contributed by union directors from the responding institutions indicated that individuals in directorship roles were primarily white males with a graduate degree. The presidents and the union directors also ranked current campus issues that union programs and services could aggressively address. The top five included the retention of students, the recruitment and retention of underrepresented populations, alcohol/drug/substance abuse, student apathy and inadequate services and programming for commuter and non-traditional students.

Articles focusing on the presence of women in the realm of university union management were virtually non-existent. One exception was a 1993-1994 series of articles in the ACUI Bulletin entitled, "Profiles of Our Profession," which examined the career paths and experiences of various student union and activities professionals at ACUI member institutions in the United States. Two women were included in the series (Parent, 1993; Parent, 1994). Both women noted that they had never planned to become a union director. Their decision to enter the field was based upon their undergraduate experiences and what one woman described as a "happy accident" (the opportunity to fill a vacant student activities position at a near-by campus). Both also acknowledged that they needed to involve their families in their careers in order to provide some sense of 
balance to their lives. One woman remarked that by including her family in work-related activities and events, "they know what you do and they have the opportunity to meet some of the special people that you work with. If you can share some of the excitement, and some of the activities and programs that go on in the union, it works real well" (Parent, 1993, p. 13).

Mercer (1990) and Swanka (1998) also examined the limited number of women in the field of university union management and potential roadblocks faced by women that might consider a union directorship as a career option. In her doctoral dissertation, Swanka (1997) traced the career paths of seven female union directors and considered the educational backgrounds, career planning, mobility and work centrality of her subjects. Although extremely useful as a reference for this study, Swanka's work lacked the detailed anecdotal data that could have conveyed the personalities and unique qualities of her subjects as well as the idiosyncratic features of the context in which the subjects worked.

Conference programs and proceedings from ACUI annual conferences contained abstracts from educational sessions that focused upon women in the field of university union management. For example, a 1991 session entitled, "Women and college unions: Present and future" addressed "problem areas" that affected female members of ACUI and possible strategies to assist in the resolution or eradication of these issues (Savage, 1992, p. 34). The problem areas included: limitations on women's participation in professional activities due to family responsibilities, the continued lack of sensitivity to women within the professional arena, the lack of representation of women in higher levels of union administration, differences in gender communication styles and disparity in pay. Suggested strategies were: making affordable on-site child care available at 
regional and annual conferences, the development of a workshop related to women in the field to be presented at regional and international levels, the development of a mentoring program for women, increased educational sessions/workshops to better prepare women for work in operations and facilities management positions and increased efforts by the ACUI Central Office to provide accurate salary information by gender (p. 35).

Four women that had been involved in construction and renovation projects at their respective campuses presented "Who's that girl in the hardhat?" at the ACUI annual conference in 1990 (Moore, Delahunty, Devaney \& Turner, 1991, pp. 62-67). They believed that their collective experiences would "be useful to anyone involved in a construction or renovation project, because of the ramifications for women in a male domain" (p. 62). One of the presenters recalled that at the initial meeting related to the construction project on her campus, the female staff members, "weren't introduced, and when we were referred to, it was as the girls at the end of the table" (p. 64). The session featured a list of do's and don'ts for women to consider. They included: learn how to read blueprints, keep everybody (including students and staff members) informed about the progress of the project, take notes at meetings and during phone conversations with individuals related to the project, share acquired knowledge with students and young professionals and act professionally at all times (pp. 66-67). 


\section{Leadership/Management Styles}

The higher education administration literature indicates that a consensusbuilding style of management is commonly associated with women in the field. Hammond (1997), Executive Director of the Student Union at California State University, Northridge, for example, promotes what she calls the "value cycle" model of management. Through its use, everyone assumes responsibility for modeling management and leadership, regardless of individual positions or

styles. As a result, the development and nurturing of the staff is shared by everyone in the facility and is not solely the duty of the union director.

In addition, Astin and Leland (1991) examined three generations of female leaders and their use of democratic, collaborative and empowering approaches to achieve success. Their findings suggested "the empowering, cooperative approaches most often associated with women are not exclusively female terrain" and could be effectively adopted by male leaders as well (Astin \& Leland, 1991, p. xii). In contrast, the twenty-three leaders included in Clark, Caffarella and Ingram's (1998) study also employed the same collaborationoriented methods, although the study's findings suggested that those approaches further stereotyped gender differences between male and female administrators in higher education.

Not all studies suggest that female university administrators have a decidedly female style of leading and managing. Street and Kimmel (1998), for instance, found that female university administrators actually tended to categorize themselves as androgynous. 
Some studies suggest potential difficulties when women do lead and manage in different ways from men. Nidiffer (2001), for example, found that women administrators in higher education were taken less seriously in the aspects of their jobs typically associated with males, such as fiscal affairs or management of the physical plant (both typically components of union directorships).

Women in union directorship positions are regularly called upon to practice leadership as defined by Hefitz (1994). They are constantly faced with tasks, adaptive challenges and swampy problems for which no definitive solutions exist. The multidisciplinary nature of their jobs also demand that they guide, interpret and stimulate the involvement of their staff and students in an effort to provide quality programs, services and resources for their respective campus communities.

\section{Mentoring and Role Modeling}

Numerous studies have validated the importance of mentoring in the retention of women in various sectors (including corporate America and higher education), their ability to advance to senior level positions and overall career satisfaction (Blackhurst, 2000; Twale \& Jelinek, 1996, Wellington, 1998). This is particularly true in the development of women administrators of color. Unfortunately, the limited number of females in senior level positions negatively impacts the ability of graduate students and entry-level employees to establish mentor/mentee relationships. On the positive side, however, women that were successful in identifying mentors early in their careers typically maintained those 
relationships throughout their professional lifetimes, even if the superior/subordinate connection ended or one or both parties changed jobs.

Wilson (2000) studied the importance of friendships on the career development of female student affairs professionals. Her research focused on female graduate students as well as women in entry-level positions within the field. Close friendships were commonly developed with classmates and colleagues as a support mechanism and as a vital source of constructive feedback. Unfortunately, the mobility required in order to advance in the field of university union management frequently led to the dissolution of these relationships. When this occurred, research subjects reported feeling a sense of sadness and loss. These data have reinforced the need for formal mentoring programs for new professionals who may experience culture shock or feelings of isolation following their arrival at a new institution.

Involvement in professional organizations has also been cited as a successful avenue to the development of both mentoring relationships and friendships. The subjects included in Swanka's (1997) study of female union directors noted that their involvement with ACUI allowed them to create a network of colleagues that they could turn to for advice or consolation, due to their shared understanding of the college union environment and commonalities inherent in their directorship roles.

\section{Women's History}

Works related to the incorporation of women into the American workforce provide an additional lens through which participants' experiences 
might be viewed. Especially prominent is the tendency of women to self-identify with their professional titles and the concept of power (or powerlessness) as it applies to women in organizations.

Gilligan's (1984) groundbreaking study entitled, A Different Voice, affirmed the need for additional research that included female participants in order to consider how male and female experiences differed in various environments. Miller's (1986) Toward a New Psychology of Women responded to Gilligan's challenge by focusing on, "women's development in the terms in which it is lived rather than to force it into the categories which we have inherited, categories that originated in the attempt by men to describe all life" (p. xviii). Belenky, Clinchy, Goldberger and Tarule (1986) continued to explore this topic with their study, Women's Ways of Knowing. Their in-depth interviews with 135 women (spanning ethnic, socio-economic and educational boundaries) attempted to "end the silence" about women in American society. The authors noted that "all women grow up having to deal with historically and culturally engrained definitions of femininity and womanhood - one common theme being that women, like children, should be seen and not heard" (p. 5).

Freeman's (1989) collection of essays entitled, Women: A Feminist Perspective, presents an historical overview of the advent and growth of the feminist movement in the United States. Particularly insightful were chapters devoted to the topics of growing up female and women in the workforce. Fox (1989), for example, notes that occupational advancement is more closely linked to education for women than it is for men and that women rely more heavily on formal credentials throughout their working lives than their male counterparts, 
who consider personal relationships or professional networks more important ( $\mathrm{p}$. 217).

Greenwood-Audant (1989) examines the concept of "powerlessness" in women who serve as full-time homemakers. She suggests that their primary roles as caregivers result in a sense of self that relied on others for approval and validation (pp. 258-259). This observation may also apply to women working outside of the home as well.

In her essay entitled, Feeling Like a Fraud, Peggy McIntosh (1985) describes the experiences of competent professional women who feel "fraudulent" despite their professional accomplishments and educational credentials. McIntosh's subjects were convinced that inevitably, they would be "found out" and would be banished from their respective fields. In her sequel, Feeling Like a Fraud: Part Two (1989), she validates women's desire to be authentic as the source of their feelings of fraudulence and encouraged both men and women to bring what she described as "the home or friendship sense" into work environments in an effort to "create whole value systems, policies and institutions which place at the center this concern for growth, development and survival without violence and with dignity for all" (McIntosh, 1989, p. 12).

Miller (1986) examines the phenomena of domination and subordination and considered how historically women have assumed positions of subordination in both their personal and professional relationships. Some of these relationships may be temporary and result in the lesser party being viewed as socially unequal (student/teacher and doctor/patient relationships were given as examples). The goal of such relationships is to provide assistance or help to the subordinate party to end the inequality. 
Miller also noted, however, that women have been ascribed (or defined) at birth as less powerful because of their gender (race was also listed as criteria of permanent inequality). She remarked that, "In our own society, a woman's direct action can result in a combination of economic hardship, social ostracism, and psychological isolation - and even the diagnosis of personality disorder" (Miller, 1986, p. 10).

Snee (1994) studied public administrators who held positions of authority over other women in their respective work environments. She found that occurrences of depression, dissociation and splitting (separation of thoughts and emotions, knowledge and desires, wants and needs, etc.) were common among these professional women. She attributes it to what she dubs "split vision" (i.e., a defense mechanism used to cope with anxiety and utilized by these women in an attempt to separate their professional and personal lives). The results of this research suggests that women frequently pay a high personal price in exchange for the contributions that they make to organizations and institutions in which they manage others.

Additional articles have addressed the possibility that women may actually create dominate/subordinate relationships with other women. Crisp (1997) pondered the importance of physical attractiveness in the professional success of women and found that women were suspicious of one another and questioned the competency of other women who achieved professional success relatively quickly. She noted that all women understood that "attractive is deliciously subjective; in other words, we're all attractive, perpetual flints wandering the earth waiting for sparking friction. There we are all then candidates for "suspicion" (p. 80). 
Ledet, and Henley (2000) studied how people perceive women in upper level managerial positions within organizations. The results of their research indicated that women in high levels of position or power were seen as masculine relative to men and women in low levels of position or power. It was also felt that the results could indicate that stereotypical characteristics attributed to women (passivity, dependency) may be changing. Instead, the authors suggested that the traits previously associated with masculinity should actually be credited to the perception of high levels of position or power.

Lorber's (1989) examination of trust and loyalty between male and female co-workers helps to explain the failure of female union directors to establish collegial relationships with male co-workers and/or colleagues. Lorber found that males felt that the possibility of any sexual relationship between co-workers diminished the ability of individuals to work together and could ultimately limit the overall effectiveness of the organization. Women with children were also viewed as "untrustworthy," as they demonstrated a divided loyalty between their job and their offspring. Males also often perceived that the needs of a child could limit women from being completely dedicated to their careers. They may not be able to work long hours or be flexible enough to attend to unexpected crises that arise (pp. 347-355).

Schaef (1992) further developed this premise by noting that the business/work environments and mores created by and for men were not applicable to the majority of the women that were entering the workforce. Despite these obvious advances in research, additional studies have indicated that women still continue to struggle with issues of self-confidence, self-image and ability. 
The feminist movement has entered its "Third Wave," a term created by writers and sociologists (Drake, 1997; Findlen, 1995; Orr, 1997; Walker, 1995; Walker, 1996) to describe the latest shift of the feminist movement and its primary foci (the First Wave concentrated o the abolitionist and temperance movements and securing the right to vote for all women and the Second Wave championed reproductive rights and the Equal Rights Amendment). In sharp contrast to its issue-specific predecessors, the Third Wave notes that the feminist movement has become far more global in its approach. With successful strides being made in the United States, gender equity for women in education, the workplace and society at-large is being taken to previously underdeveloped nations.

In recent years, the words "feminist" and "feminism" have taken on negative connotations. Schrof (1993) noted that the third wave of feminists are "acutely aware of their predecessors' reputation for being hateful to men, focusing on too narrow a set of goals and marginalizing minority and lowincome women. Eventually the "third wavers" also hope to "eradicate the image of feminism as a rich white woman's club" and have called for a "radical overhaul" of the movement to include previously unrepresented groups of women (Schrof, p. 70).

Dailey (1991) recognized this trend and addressed the opportunity to educate students in university union settings and demonstrate ways to "move past narrow gender roles into balanced leadership styles" in an educational session presented at the ACUI annual conference entitled, "A harrowing experience: Finding common ground between feminism and student development." (p. 92). In her session, she described the personal struggle she 
had faced as she tried to incorporate her personal feminist philosophy into her work, at the risk of alienating her students and co-workers. She was particularly challenged when she discovered that one of the more successful studentsponsored programs on her campus had been a wet t-shirt contest.

Instead of speaking out against that particular program, Dailey worked with her students to create new programs to change her campus' culture and values. Dailey was aware of, "the neat fit between feminist pedagogy and student development theory as well as the similarity of values between feminist and student affairs perspectives" (p. 92). She also noted that accommodating (or feminine) leadership styles (including cooperation, teamwork, empathy and collaboration) could easily be blended with more conventional (or masculine) styles (such as competitiveness, analytical ability, rational thinking) to allow students and young professionals to gain self-confidence (p. 93). Dailey challenged other student union professionals to help their campus communities "create events and rituals that support and affirm students and communicate the student union vales and vision" (p. 94).

Finally, a number of recent studies have chosen to examine women's history from the perspective of women as goddesses (Bolen, 1984; Brockway, 2002; Eisler, 1995;) These works proved to be insightful in examining the leadership styles of the women included in this study and their ability to succeed in a male-dominated profession. Eisler (1995), for example, felt that ancient civilizations had originally been agrarian and matriarchal in form and that goddess worship was actually practiced. This model was eventually replaced by a patriarchy or dominator model, which ranked one half of humanity over the other (p. xvii). Eisler challenged historians and practitioners to consider a third 
possible model that promotes partnerships or linking between men and women to "more effectively intervene in our own cultural evolution" (p. xxi).

Bolen (1984) encouraged women to identify their "inner goddesses" to further develop their potential as leaders, professionals, homemakers, mothers and lovers. She noted "there are many goddesses in an individual woman. The more complicated the woman, the more likely that many are active within her. And what is fulfilling to one part of her may be meaningless to another" (p. 2). This analogy was useful in understanding the different views of success that were held by the female union directors in this study and their ability to balance their careers in university union management with additional roles as wives, mothers, partners, community activists and volunteers, etc.

Brockway's (2002) A Goddess is a Girl's Best Friend was created as a selfimprovement manual for women. Legends and folklore connected to a variety of goddesses from cultures are used to communicate lessons related to love, loss, success, happiness and spirituality. The creation and use of support groups was also encouraged. Brockway stated that:

When women gather with the intention to grow and heal and evolve - on a personal, professional and planetary level - everyone benefits including the women present, their families and the world. The ripple effect can really help, in some small way, to transform our world as it transforms our lives (p. 268).

The concept of women supporting each other was evident in the data provided by the respondents to this study and can also be seen in the use of mentoring and role modeling by the female union directors included in the research sample. 


\section{Education, Training and Career Development}

Graduate programs in higher education administration, college student personnel and counseling help prepare men and women for a multitude of career options that fall under the auspices of student affairs on college campuses, including union management. Veteran union directors have frequently remarked that they "fell" into the field (Mercer, 1990). Many became involved in union management as the result of a positive undergraduate experience that may have included a work-study position in the campus union or a stint as a student government officer.

While few individuals grew up with the expectation that they would become a union director (Mitchell, 1999), the majority of today's union directors hold some type of graduate degree. Morton's (1999) study of 118 union directors at research and doctoral 1 universities indicated that graduate programs in higher education administration were viewed as the preferred discipline by individuals that participated in the project (57.7\%). Additional educational choices included student personnel (47.7\%) and business management (31.5\%). The directors that served as research subjects in Morton's study also felt that, in the near future, a master's degree will be required to obtain a union directorship, and over one-third of the respondents noted that a terminal degree will quickly become the minimum educational requirement for candidates for union positions in years to come.

Concern about the effectiveness of college student affairs programs to adequately prepare individuals to enter the field of union management (Ratcliffe, 1998) has led ACUI to develop a list of competencies that are recommended for 
incorporation into both college degree program curricula and practical training experiences (Morton, 2003). Human relations skills far outweighed cognitive and technical skills in importance in the list of competencies, as it was felt that the ability to work effectively with others directly impacted the union director's role as an organizational and campus leader and successfully supervise professional and managerial personnel. Examples of important technical skills included budget/fiscal management, the generation of revenue, facilities management and previous work experience in higher education. Desirable cognitive abilities included strong organizational skills, the ability to build relationships with other members of the campus community, strategic planning and policy development (Morton, pp. 48-49).

Unfortunately, many graduate programs still fail to include coursework related to women in their curricula (Blackhurst \& Hubbard, 1997; Evans, 1988). This oversight limits the amount of accurate information that female higher education administrators receive regarding equity in pay and job opportunities, the importance of pursuing a mentoring relationship, career advancement and job satisfaction. If gender-related courses are included in graduate programs, they are offered as electives. Even though the majority of individuals entering the field are women, graduate courses related to college student personnel are taught primarily by male faculty members. In her examination of the "new scholarship for women," Nancy Evans observed that, "The academic environment is by nature competitive, hierarchical and male dominated. Student affairs preparation programs, located within such a context, often assume these qualities as well" (Evans, 1988, p. 500). 
As with other professions, additional training and educational opportunities have been developed to supplement the formal and practical training experiences offered by graduate programs. Organizations such as the Association of College Unions International (ACUI), the National Association of Student Personnel Administrators (NACA) and the National Association for Campus Activities (NACA) annually offer a variety of conferences, workshops, seminars and colloquia to student affairs administrators. Recent ACUI seminars have focused upon assessment, building renovation and construction, late night programming and hate crimes (www.acuiweb.org).

Materials and publications relevant to the field of university union management continue to provide additional opportunities to share information and cutting-edge concepts. Examples include the ACUI Bulletin, the NASPA Journal and NACA's Programming magazine.

The career path to becoming a university union director can be long and arduous, lasting years, even decades (Swanka, 1997). This is especially true for women, who typically begin their student affairs careers as student activities staff members, as such positions are viewed as most compatible with the stereotypical female management traits of collaboration and caring and involve regular interaction with students, faculty and staff members (Mercer, 1990, p. 19). Women are often overlooked as potential candidates for union director positions as they are seen as lacking knowledge and practical experience in the areas of facilities management, construction and fiscal processes that are commonly associated with most union directorships (Mercer, p. 18).

Although it is not known how many women leave the field if they fail to obtain a union director position, studies have indicated that women leave the 
student affairs profession in significantly higher numbers than men (Burns, 1982). Reasons for their departure included lack of career mobility, lack of available mentors and increased challenges imposed by attempting to balance a career in student affairs with family life (Nobbe \& Manning, 1997).

While research has recently been conducted on the relationship of career development to the organizational commitment and life satisfaction of female student affairs officers, changes in academic culture and the flexibility and support of supervisors needed by women union directors with families have been slow to emerge. One study noted:

As members of a profession dedicated to holistic development and personal wellness, student affairs practitioners must be willing to address quality of life issues for members of the profession as well as for the students they serve. Doing so will not only improve the satisfaction and retention of women administrators, but it will also provide positive role models for undergraduate students, and perhaps more importantly, for graduate students in college student affairs programs" (Blackhurst, Brandt \& Kalinowski, 1998, p. 31).

\section{Balance}

In the 1920s, approximately 20\% of American women held jobs outside of their homes. By the end of the twentieth century, that number had tripled to $60 \%$ (www.workforce.com). As more women entered the workforce, the issue of balance has grown in importance and has served the topic for a variety of studies produced during sthe past ten years. Bolton (2000) described a "third shift" 
adopted by most working women as time devoted for reflection and selfdiscovery that needed to be sandwiched between those hours already devoted to work and family. Padulo (2001) and Nobbe and Manning (2000) found that female student affairs officers must perform a complex "balancing act" in order to have both a career and a family. Both authors encouraged employers to consider flexible schedules and job sharing as possible options for female subordinates with families.

Black Issues in Higher Education recently devoted two entire issues to the struggles faced by female faculty members and administrators on campuses in the United States. Anayaso (2002) suggested that women who achieved tenure frequently sacrificed childbearing for their careers. A study released by the University of California-Berkley in 2002 noted that $62 \%$ of women in the humanities and social sciences and $50 \%$ of women in the hard sciences did not have children 14 years after being granted tenure. This figure was compared with $39 \%$ and $30 \%$ percent for tenured male faculty members in the same academic disciplines.

Hamilton (2003) posed the question, "Can women in the academy have it all?" She found that a number of women had recently left their families and relocated to accept their "dream jobs" as provosts, vice chancellors and presidents at various campuses throughout the country. The majority of the women interviewed for the article had children in high school or college and were able to leave the primary care of their offspring to their spouses. Technology (email, voicemail and fax) allowed them to communicate easily with their families, despite the geographical divide. Yolanda Moses, president of the American Association for Higher Education has labeled the balancing act 
practiced by working women as the "double day" (Hamilton, p. 25) and noted that:

The reality is that most women in the United States still lead a double life - the life they lead in the workplace and the university and then the life at home. Men are doing more, but the majority of women are still responsible for what is essentially two jobs. Even where there is help it's usually the woman who organizes and makes sure that the help is there.

\section{Summary}

While the literature reviewed for this study is informative, it does not directly address the experience of female university union directors. And although female union directors were included in many of the research samples, the results were extremely general in nature, which makes it difficult to disaggregate findings and apply the data to any one particular sub-population. This was also true of works that detailed the entrance of women into American corporate culture. While they may provide some psychological and sociological background, they also lacked the specificity that was essential to be truly applicable to the sample considered in this study.

Research related to women in the field of higher education administration and university union management has been slow to evolve. And even though studies have begun to emerge, only a small number of female researchers/investigators are exploring the issue. Moreover, there is an obvious void in the area of research devoted to the experiences of women of color in the field. It is important to examine how their career development and overall 
satisfaction varies from that of majority females in an effort to ensure the inclusion of this valuable population within the realm of university union management.

The literature reviewed for this study continues to support the need for further study on women in higher education administration, especially those that hold middle management positions, such as university union directorships. Due to the unique responsibilities associated with daily life in the university union setting (maintenance, staffing, budgeting, retail operations, etc.), the current literature is far too general in scope to speak to the experiences and needs of this particular population.. As the feminization of student affairs continues into the twenty-first century, it is particularly important to consider how the maledominated realm of academia evolves to meet the changing needs of female administrators. The study that will be described in this next chapter is an attempt to begin to respond to this need. 


\section{CHAPTER THREE}

\section{METHODOLOGY}

A review of the literature relevant to the history and philosophy of the university union movement strongly suggests that women have become increasingly visible as staff members in college union settings, representing 47 percent of all staff positions. In the role of director or executive director, however, women remain significantly underrepresented, holding only 29.4 percent of such positions (ACUI, 1998). The purpose of this study was to better understand the scarcity of women in positions of executive director or director in university union settings.

The following research questions guided this study:

a.) According to the female university union directors' perceptions, what effect, if any has their gender had on their ability to obtain a directorship position within the field of university union management?

b.) According to the female union directors' perceptions, what effect, if any, has gender played on their ability to succeed within the field of university union management following their promotion to a directorship position?

c.) According to the female union directors' perceptions, what effect, if any, has their decision to pursue a career in university union management had on their personal lives? 
This chapter focuses on the methods used to answer the above questions. The following topics are discussed: qualitative research, the committee on the protection of human subjects, data collection and data analysis.

\section{Qualitative Research}

This research project employed a qualitative case study/cross case analysis design. The use of qualitative research has become relatively common in the fields of history, psychology, sociology and education. Over the past three decades, a number of seminal works have appeared in an effort to promote the value of qualitative research and offer instruction on the processes involved in utilizing this specific paradigm. Particularly significant were Lincoln and Guba's (1985) Naturalistic Inquiry, the second editions of Patton's (1990) Qualitative Evaluation and Research Methods and Glesne's (1999) Becoming Qualitative Researchers and the third edition of Bogdan and Bilken's (1998) Qualitative Research for Education: An Introduction to Theory and Methods. These texts offer an historical perspective to the development of the qualitative methodology from its earliest inceptions via the Chicago School in the 1920s and 1930s, to the current uses to study a wide variety of topics including the experiences of underrepresented populations, including women and people of color.

A key word search of various databases (using the designator "qualitative research"), revealed nearly 2,000 articles related to the preparation, analysis and publication of qualitative research. A recent series of articles included in the journal entitled, Education for Health: Change in Learning and Practice, continued the work of earlier researchers by describing the relevance of the use of 
qualitative research and its applicability to both medical and social science genres. Frankel and Devers (2000a) offered a concise overview of the basic differences between qualitative and quantitative research designs, the primary components essential to a useful qualitative design, the development of research questions, the formation of the literature review, the definition of the intended research audience and the successful determination of the primary research audience.

Frankel and Devers (2000b) also focused on sampling and data collection strategies, recommending a purposive sampling technique in order to "enhance the understanding of selected individuals or group experiences" (p. 264). The authors also stressed the need to recognize the role of the researcher and the concept of the researcher as instrument introduced in earlier texts.

Like its quantitative counterpart, issues of reliability and validity are also paramount in qualitative research. Johnson (1997) offered twelve strategies to promote research validity in qualitative studies, including considering the researcher as "detective," conducting fieldwork over an extended period of time, using low inference descriptors (such as direct quotations), and the use of triangulations to corroborate data.

\section{Reasons for Using Qualitative Research in this Study}

The questions created to guide this study could not be answered using conventional (i.e., quantitative) methods. A qualitative research design allowed for an increased understanding of the situations, experiences and meanings of a unique group of people (Frankel \& Devers, 2000a). As the reality found within a university union environment is socially constructed, complex and everchanging (Glesne, 1990, p. 5), the interpretivist/constructivist perspective which 
grounds most qualitative research was appropriate for this study. The use of thick, rich description was employed in an effort to create verisimilitude for the readers. This level of detail also served to reinforce the credibility of the data and its applicability to similar settings or contexts.

\section{Case Study Approach}

The case study approach was selected in order to organize and present the data collected from each of the participants in a comprehensive, systematic and in-depth manner (Patton, 1990, p. 384). Individual case studies were constructed through the compilation of the raw case data, construction of case records and the creation of written narratives to allow for an increased understanding of each subject and her unique experiences in the unique context in which she worked (Patton, p. 388).

\section{Cross Case Analysis}

Although each case is rich with detail and insight, an objective of this study was also to provide some sense of patterns that cut across individual cases and particular contexts. This required that a cross case analysis be conducted. This cross case analysis involved grouping together the participants' responses to the common questions that were presented to them (on the participant profile and during the interview sessions) and analyzing different aspects that related to the central issues of the study (their daily experiences, career paths, success in the field, impact of career on personal lives, impact of gender on their role as a union director, gender equity in the profession).

The use of cross case analysis was effective in the identification and extrapolation of "lessons learned" by the subjects included in the research sample (Patton, p. 425). Differences were as important as similarities in 
generating these lessons. While women employed as directors of university unions served as the primary focus of this study, there were distinct variations in their career paths, leadership styles, personal lives and feminist identities. The cross case method allowed the subjects to retain a sense of individuality and uniqueness, yet offered a way to group the data into organized categories/themes. Inevitably, patterns emerged that indicated trends or similarities related to this group, but did not reduce participants' experiences or perspectives to a single "norm." (Glesne, 1999, p. 5).

\section{Committee on the Protection of Human Subjects}

Discussion of the contents of the participant profiles and interview sessions could be extremely sensitive or politically damaging to the women included in this study. Prior to their participation in the project, each respondent received an informed consent form (Appendix A) that provided them with information related to the study, including potential benefits and risks (which were minimal). Because participation in the study was entirely voluntary, participants were able to withdraw from the project at any time. The subjects were also informed that they could request a copy of the transcript of their individual session and edit or revise the document, if desired. No such requests were made, however.

This research design was approved by the Committee on the Protection of Human Subjects at the University of San Diego as a class project in Spring 2001. Approval was extended to cover dissertation work in Spring 2002. 


\section{Data Collection}

\section{Participant Selection}

The membership directory of the Association of College Unions International (ACUI) served as the primary source for the identification of potential subjects for this study (ACUI, 1999; ACUI, 2002). Founded in 1910, ACUI serves as the premier organization for staff and students that work in university union settings around the globe. The memberships of the National Association of Student Personnel Administrators (NASPA) and/or the Association of College Personnel Administrators (ACPA) were not considered as sources for potential subjects as both organizations tend to attract individuals that hold (or intend to hold) upper-level administrative positions in the student affairs arena (assistant deans, deans and vice presidents) that typically do not include the union director position.

Four women were selected and invited to participate in an initial study that was conducted in Spring 2001 as an assignment for a course in Advanced Qualitative Research offered at the University of San Diego. The sample was, in part, a convenience sample, but there was an attempt to maximize variation in terms of age, longevity in the field of university union management and the size and scope of the facility under the respondent's pervue. Three of the women selected were actually interviewed. The fourth was unable to participate due to a scheduling conflict.

A "snowball" or network sampling approach was adopted to identify additional subjects and expand the sample to nine. The three subjects included in the sample for the pilot study were asked to provide names of other female 
union directors that fit the basic criteria for the study (i.e., had the title of director or executive director, had held their current position for a minimum of two years and could be considered "successful" in the field of university union management). Eight potential subjects were identified using this technique and were invited to participate in the study. Six of these women accepted and were included in the final research sample. The two other women identified as potential subjects failed to respond to phone calls and email messages sent by the researcher and were subsequently eliminated from the group.

The respondents included in the study were extremely diverse in age, ethnicity and life experiences. The youngest participant was in her late 30s, while the eldest was in her late 50s. The sample included one African American and two Asian American women.

Each of the participants had been active in the field of union management for more than ten years and eight had been employed at their current worksite for a minimum of two years. This criterion was established in an effort to ensure the credibility of the subjects' responses as well as the overall validity of the data. One additional subject that has held her position for less than one year was also included in the sample to consider how her experiences compared wit those of the women that are considered to be seasoned veterans in the field.

Potential subjects were first approached via electronic mail and/or telephone and invited to participate in the study. After agreeing to participate, individuals were sent an informed consent form (Appendix A) and a participant profile/questionnaire via email (Appendix B). The completion and return of these documents was required prior to the scheduling of an interview session with each of the subjects. 


\section{Participant Profile/Questionnaire}

A two-page questionnaire was developed to collect preliminary information from each of the nine participants based on an instrument used by Astin and Leland (1991). Particularly significant were the age, educational background, employment history and current salary of each subject. Participants were also asked to comment on the most and least rewarding aspects of their jobs, the impact their careers have had on their personal lives, their ability to serve as mentors and their views regarding gender equity for female union directors.

All of the responses to the participant profiles were received by email or fax. The completed questionnaires were reviewed and information was transferred to index cards to allow the data to be sorted or categorized during the cross case analysis phase of the study. Responses to the open-ended questions were carefully reviewed to consider possible probes or follow-up questions that could be included in a subject's interview session.

\section{Interview Guide}

An interview guide (Patton, 1990) was adopted for the interview sessions to allow the sessions to remain conversational and flexible, while also ensuring that the same material was covered with each of the subjects included in the sample and allowed for consistency in the information provided by the participants. Furthermore, the use of an interview guide also helped to make the best use of the limited time that was spent with each subject and ensured that the predetermined topics of this study were addressed, albeit in a relaxed and moreor-less natural manner (Patton, 1990, pp. 376-378). A copy of the interview guide is included in the appendices of this report (Appendix C). 


\section{$\underline{\text { Interviews }}$}

All interviews began by asking respondents how they viewed their role as a union director. Additional "grand tour" questions such as "Could you describe a typical day at your union?" were also included. Example and opinion questions were formulated to generate data about the perceived effect of the participants' gender on their ability to establish competency within the field of university union management and their perceptions about the impact their career choice has had on their personal lives. Although each subject was asked the same basic questions, additional, specific inquiries were developed based upon participants' responses and review of the information provided on the written instrument/profile.

The average length of each interview was approximately 45-60 minutes. All interviews were audiotaped and transcribed. Field notes were also taken during each session to record additional details related to each participant (voice inflection, body language, facial expressions, etc.).

A typist or transcriber was not hired to complete the transcriptions as the researcher wanted to take the opportunity to review the audiotapes. It was felt that an outside participant would potentially miss the "essence" of the responses offered by the subjects due to a lack of familiarity with the subject matter. Thus, tapes were transcribed by the researcher. In all cases, this was done within 72 hours of the completion of each interview in an effort to preserve as many details as possible from each session. Each transcription took approximately 10 hours to complete and produced 18-20 pages of text. 


\section{$\underline{\text { Researcher Role }}$}

While the researcher had prior interaction with some of the participants through ACUI conferences and activities, it was never felt that any previous contact would compromise both parties' ability to remain objective throughout the study. And, although the researcher has worked in a university union setting, she has never aspired to become a union director. The operational and logistical aspects of such positions, while admirable, are not attractive to the researcher. Existing professional and collegial relationships within ACUI facilitated the establishment of rapport with each subject and proved to be beneficial during the data collection process.

Due to the researcher's professional experience in the field of student activities, familiarity with the everyday workings of a college or university union allowed for an increased understanding of the scenarios and crises faced by the participants as well as jargon and terminologies included in interview responses. As a result, additional research related to the day-to-day function of union facilities was not conducted.

The fact that the researcher played an integral role in the overall success (or possible failure) of this study remained paramount throughout the duration of the project. Thus, the researcher made an effort to ensure that high levels of professionalism and respect towards the participants was offered at all times and readily conveyed the integrity of the researcher and the study (Frankel \& Devers, 2000, p. 268). 


\section{Data Analysis}

Data analysis was undertaken simultaneously as data were collected to allow the researcher to focus on the topic and modify the study as it unfolded (Glesne, 1999, p. 130). A three-ring binder was used to organize the massive amounts of data accumulated during the data collection phase. Individual sections were created for each of the nine subjects. Each section contained the signed informed consent form, completed participant profile and interview transcript and field notes for each respondent.

Analytic files were also developed to hold supplemental materials related to the study. File headings included:

-Qualitative Research

- Feminist Theory/Women's History

-Women and Power

-Quotations

All of the interview transcripts were hand-coded. This decision was primarily based upon the researcher's need to review all of the data and look for common issues and themes (as well as significant discrepancies). Furthermore, it was decided that the "voices" of the participants and their unique experiences would have been diminished if the data was sorted by computer or quantified in any way.

An initial review of the participant profiles and interview transcripts revealed the following themes:

-University Union Management

-Women in Higher Education Administration 
-Education/Training

-Leadership/Management Styles

-Ability to Balance Personal and Professional Roles

-Mentoring

- Feminist Identity

- Future of Women in the College Union Field

Documents were coded and data associated with the major themes listed above were highlighted using a color-coding system (with different colors for each theme). After coding was completed, significant pieces of data were transferred to index cards. The cards also contained the participants' pseudonym as well as possible sub-headings or categories that the information could fit into. The index cards were filed under the themes listed above.

A large matrix was also created using white butcher paper and magic markers. This mechanism helped to assemble the demographic data from all of the participant profiles and provided a visual reference for this study.

The coded transcripts and questionnaires were extremely useful in the preparation of individual case studies for each subject. The cases have been developed to allow the separate personalities of the women to remain unique. Each case includes anecdotes or vignettes that appeared to be particularly significant to that woman's identity as a university union director.

The matrix and index cards also were instrumental in conducting the cross case analysis. While a number of similarities were noted among the women included in the sample (work environment and campus size, for example), a considerable number of contradictions were also found (i.e., educational 
background/training, ability to self-identify as a feminist). These will be discussed in detail in the findings section of this document.

\section{Summary}

The qualitative case study/cross case analysis design utilized for this project allowed for an increased understanding of the situations, experiences and meanings of nine female university union directors. Case studies were constructed and presented in a narrative form to allow the individual personalities of the participants to emerge. The use of cross case analysis grouped the data into organized themes and provided a sense of the patterns that cut across individual and particular contexts, resulting in the emergence of trends, similarities and differences that were significant to understanding this particular population. 


\section{CHAPTER FOUR}

\section{FINDINGS}

The legends and myths associated with goddesses are typically full of colorful characters, chaos and crises and meaningful lessons. The stories of the goddesses included in this study followed a similar format. A case study was created for each of the nine participants in order for the reader to better understand the complexity of each woman's reality (including daily responsibilities associated with serving as a union director, leadership/management styles and the impact of career choice on their personal lives and vice versa) and to respond to the research questions that were used to guide this study. Quotations and other data collected from the participant profiles and oral interviews have been included to ensure that at least some of the uniqueness of each respondent is maintained and their individual voices are heard.

\section{Case Study One: Ann}

\section{$\underline{\text { Role as a Union Director }}$}

Ann is an African American woman of color in her late forties. She has served as the director of the same facility for more than a decade. She described her role a union director as "multifaceted," but particularly enjoyed what she considered 
to be her primary roles: facilitator of student development and manager of a business operation. And while the challenges of running a business (i.e., staff development, financial planning and strategic direction) were clearly important to her, Ann stated that she never wanted "the business side to overshadow the student learning imperative." She felt that she and her staff were able to put students first by creating a clear and concise mission statement, providing comprehensive training for students and professional staff members and basing "bottom-line" decisions on how they related back to the mission.

Description of a Typical Day

Time management and organization played a definitive role in Ann's daily routine as a union director. She noted that her average day begins at 5 a.m. and that she spends two to three hours at home preparing for her day. "I read things that people have asked me to review, get back to them (via email or voicemail) and then do some things that take more concentrated time, because I don't seem to have a whole lot of that in the office," she said.

After arriving at her union, Ann's schedule typical includes an average of six meetings. She maintains an open-door policy for students and staff members. She explained why this is important to her: "I want them to know that someone cares about them and that they're going in the right direction." She also practiced "management by walking around," in an effort to "see what people are doing, see where people are hanging out, where people are not hanging out." During her daily walks through the building, she also checked the condition of the various areas and noted needed repairs or improvements. 


\section{Leadership/Management Style}

Ann described her management style as that of situational leadership and explained that she assessed each person, which allowed her to better supervise them. She also noted that she is very committed to participatory management and frequently seeks input from her employees before making a decision. She regularly delegates projects or tasks to others to provide them with opportunities for learning and to empower them.

Ann viewed her leadership style as "totally opposite" from the authoritative model utilized by her male colleagues, including her two supervisors, who were both men. She saw herself as inclusive and tried to "make decisions at the lowest level possible." She felt that the benefits offered by giving her students and staff "the flexibility to be creative, innovative" far outweighed the direct approach of "telling people what to do and how to do it," an approach that she has seen practiced by her male counterparts.

\section{Impact of Gender on Ability to Succeed}

Because she is a woman of color, Ann found it difficult to discern whether or not her gender has limited her ability to succeed in the field of university union management. She remarked that, "It's very hard to separate race and gender from other things." She described a circumstance early in her career when she accepted an "acting" position in the student affairs division of a large, state university and was only paid eighty percent of the set salary for her work. She remembered, "I was just so excited to have a full-time job, I was like, no problem." But when she took on another "acting" role and was still denied full pay, she questioned the ethical basis for the policy. Her attitude was, "I have to 
pretty much tell people what I need and what I want and how this thing is impacting me."

Ann also expressed her concern over the tendency for women to be "trapped into doing the programming thing and not being allowed to do the operations and management side" of union administration. She encouraged all of the young professionals on her staff to explore the various aspects of union management in an effort to diversify their experience. She stated, "If you want to be a union director, you need both of these things. And the things that really get you into trouble are personnel issues and money."

Frustration was evident in Ann's responses when she discussed her views related to the topic of equity for women in union director positions. Regarding pay, she noted, "I think we'll always be behind, at least in my lifetime. I don't see that necessarily changing." She created a salary survey and distributed the instrument to other directors to support her request for a salary increase at her own institution. She has shared this survey with other female union directors to allow them to petition for more money at their campuses as well.

\section{Crisis Management}

Ann worked in a tent for nearly six months after her facility sustained damage as the result of a natural disaster as was declared unsafe. When asked to describe a crisis at work, however, she chose to focus upon a personnel issue that had gone awry. She recalled:

With the [natural disaster that impacted her campus]...it just happened. We had no choice but to get there, do what we needed to do. Get my staff together and say, this is what you guys need to 
do from home. This is what you can't do. Don't worry about this. We'll go forward.

In contrast, Ann described staff-related issues as "a huge thing" and noted that for her, personnel problems were actually "gut wrenching." She remembered:

I think the...natural disaster that destroyed our union was a crisis in the sense that it was an emergency situation, but then you just kick into emergency mode. I think my biggest crises have been personnel-related. Dealing with issues related to staff people that I really like and really care about and they're not doing what they need to do for a variety of reasons.

\section{Mentoring and Role Modeling}

Mentoring has played an important role in Ann's career development (as both a protégé and a mentor). She recalled, "It's been men and women and it's been Black and White. Because I don't think you have to have one or the other. I think it's people that tend to give." She encouraged "learning the best from the best. Learning a bit from every single person." She informally mentors students through emails, phone calls, discussions at meetings and conferences and educational presentations. She has also taught a graduate course offered through the Educational Psychology and Counseling department of her university. Graduate assistantships available in her union provide additional practical experience to students planning to enter the field and have resulted in mentoring relationships as well.

Ann noted that serving as a mentor was a way to establish her own legacy and remarked, "I think it is up to us as individuals to start telling people how 
great and wonderful this career is and attracting people to it." Ann considered mentoring a selective process, however, and admitted that "it has to be the right person." To her, mentoring students and encouraging them to enter the field of university union management was about "planting seeds."

\section{Impact of Career on Personal Life}

Ann's outlook on the impact that her career has had on her personal life is profoundly positive. She felt that her career has been extremely rewarding and allowed her to be of service to others. While she described herself as single, she also noted that being part of a "close-knit family" and a broad circle of friends offered the support system she needs and provides a sense of balance to her life.

Ann tried to take brief vacations through the academic year and noted "the balance for me comes in knowing when to take down time." She also told her staff, "Tell me when you're overwhelmed" and realized that some of her employees needed to develop more flexible work schedules in order for them to perform more effectively. She stated, "I give a lot more flex time. I have one person who is our human resources person. They don't even come into the office. They just work at home."

\section{$\underline{\text { Summary }}$}

Ann has worked in the field of higher education administration for twenty-three years and has spent fifteen of those years as a union director (at two different institutions). While she noted that she "kind of fell into" the field of higher education administration, she couldn't see herself working in any other environment. She remarked that there seemed to be more gender equity for women in the field then when she obtained her first full-time position. Seeing herself as a mentor, Ann encouraged young professionals (especially women and 
individuals of color) to gain expertise in a variety of areas, including programming, operations, administration and finance to ensure that they will gain the competencies required of union directorship positions.

\section{Case Study Two: Barbara}

Barbara is a Caucasian woman in her late fifties. She is married and has adult children and grandchildren. She has served as the director of her student union for nearly twenty years. The facility is located on the urban campus of a public university.

\section{$\underline{\text { Role as a Union Director }}$}

Barbara admitted that her perception of her role as a union director has changed over the years. She remarked:

I see myself now as a teacher and a mentor in addition to being the administrator that has to do all this and make sure that the building and the programs function at the level that we want them to function. I think that when I first came into the profession, I saw myself more as just the administrator, the person who made sure the building was okay. As the job has evolved and the union's gotten bigger, we added more programs. I hadn't really thought about the fact that between student affairs and the union, we are all teachers. We provide students with opportunities.

\section{Description of a Typical Day}

She enjoys the flexibility of her job, but her description of a typical day suggested that there is still considerable structure to her work. Her day includes 
arriving at work between 8:30 and 9:00 a.m., checking email, attending five meetings and interacting with her staff. She confessed that she has a tendency to be task-oriented, which, she indicated, sometimes limits her efforts to take time to personally connect with employees and students.

Technology has actually increased Barbara's workload. Having recently purchased a laptop, she regularly takes work home. She stated, "The workload's just astronomical and it keeps getting more so." She has, however, made the decision not to take her computer with her to conferences, "the laptop is at home waiting for me to plug-in when I get back," she stated.

\section{Leadership/Management Style}

Classifying her leadership style as "participatory," Barbara indicated she is determined not to micro-manage her staff. Instead, she tries to "recruit the best possible people. She added, "We've got to let them do their jobs. We give them the resources as best we can, whether financial or otherwise, training and that. And then, you've got to let people just do their jobs, because there's not one right way to do a job."

\section{Impact of Gender on Ability to Succeed}

While she stated that she has never felt that her gender has limited her ability to succeed as a union director, she is quick to recall that she experienced some type of discrimination when she applied for an Associate Vice President position at her campus. A male candidate (with a Ph.D. which she does not possess) was hired instead because the Vice President was "star-struck" by the candidate's educational background and prior employment at a high-profile institution. Barbara also recalled another female administrator within the student affairs division on her campus whose starting salary was significantly 
less than the man that was hired to fill the same position only three years later. She observed, "That's more of a political situation than a gender situation." Overall, Barbara felt that one of the biggest challenges she has faced has been "getting other folks to understand the complexity of the job."

\section{Crisis Management}

Like Ann, Barbara's example of a crisis she had faced in her role as a union director was personnel-related. She recalled a situation that resulted in the termination of an employee with whom she also had a close personal relationship. She admitted:

It really taught me that there has to be a fine line. You can be too close to people and to work associates, but if you start doing too many things outside of the workplace, then you literally can get into those kinds of situations where when you have to do any kind of discipline, then it's a lot tougher.

As a result of this particular incident, Barbara realized that "I needed to separate myself [from her staff members] in the future."

\section{Impact of Career on Personal Life}

Barbara's perception of how her career has impacted her life was honest and mixed with emotion. On the positive side, she noted that her role as a union director has made her, in her words, "a much more well-rounded person. She added:

I tend to see things from many more angles than I did in the past. Things are never black and white. I've had wonderful travel opportunities to see places I might not have seen otherwise. I think 
my working at the university provided the positive influence for my children to ensure that they get a college education.

She lamented, however, that she has "lost sleep worrying about budgets and student fee referenda."

Summary

Barbara's entry into the field of higher education administration "wasn't really planned." Widowed at a young age, she applied for a student activities position at a campus near her home in order to support her children. Three years later, she accepted an "emergency appointment" and began serving as the coordinator for the student union for the same institution. She lobbied to have the position title changed to director the following year and has remained in the same position for over twenty years, supervising the construction of new facilities and increasing the staff to meet the needs of the institution's community.

Because Barbara had spent her entire career at the same institution, she felt that her views related to the impact that her gender had played on her ability to succeed in the field were somewhat limited. She was aware, however, that other male directors within the student affairs division on her campus received higher salaries and had requested an equity adjustment.

Barbara balanced her roles as a single parent and the director of a university union by bringing her children to campus with her. She noted that they had thoroughly enjoyed "growing up" at her union and felt that because they spent so much time at work with her, "there was never any doubt that they would go to college when they were older." 


\section{Case Study Three: Carol}

\section{$\underline{\text { Role as a Union Director }}$}

In her late thirties and divorced, Carol has served as the director of the same facility for three years. She viewed her role as that of a coordinator, albeit a coordinator who also sets a direction for the organization. She stated, "Student unions have so many different functions and roles and responsibilities. I think part of my job is to keep those activities and functions coordinated." Then she added that her position required her to be more of a "direction setter," as:

Just coordinating would be just keeping things the same day to day and I don't think that's what we're all about either. Keeping up with trends, keeping up with student needs, keeping up with all of the things that impact what we do and how we do it and keep us moving in the right direction.

\section{Description of a Typical Day}

Carol's description of her typical day included three to four hours of meetings. A large portion of her workday was spent "just trying to keep in touch with all of the things in the office." Examples included, "returning phone calls, responding to emails, dealing with facilities-related issues that come up. And those seem to pop up when you least have time for them." She rarely takes work home with her and stated, "I'd rather stay in the office and work an extra hour or so at night and go home and not have additional work to complete."

\section{Leadership/Management Style}

At one time, Carol would have described her leadership style as "management by walking around." The current expansion project associated 
with her union, however, has limited her ability to leave her office. Instead, she delegates "both responsibility and authority to my staff and give them the ability to set their part of the operation up the way they want it to operate and then I support them." Carol struggled with her ability to be completely inclusive in her decision-making practices and stated that "because of the games you have to play to get things accomplished" she had been unable to include students and staff in decision-making to the extent that she would have liked. She noted, "I don't like to make them think that they have input or control over a decision that's really being dictated from somewhere else."

Carol was reluctant to consider herself a visionary leader because she felt that she was not:

Out there on the cutting edge. I'm really more, at this point, reactive than being out there in the front. I think to be a visionary, you have to really be able to delegate all the day-to-day things and focus your time and attention on the future and moving forward part. I don't have that leisure right now to do that.

\section{Impact of Gender on Ability to Succeed}

Carol felt that her educational background (a bachelor's degree in business and a master's degree in public administration) and her previous work experience in resident life and university union operations provide a "level playing field" and allowed her to feel comfortable in a male-dominated field. And while she noted that gender may be limiting to women in other areas of academia, she also observed that "being a women does not limit you in student affairs." She indicated that men and women in student affairs positions frequently hold similar philosophies and adopt similar methods and techniques 
when working with students and staff members. She stated, "I guess in student affairs men are more sensitive to people issues and the people side of what we manage." She also noted that:

There is a distinct difference [between] men in administrative affairs...their style and approach....and men in student affairs and their style and approach. I think that men in administrative affairs tend to be less concerned about the people side of the decisions they're making, less sensitive to the impact that an approach is having on the individuals involved in the issues. And again, I think that's because they're less in touch with the students and they're more focused on numbers and more concerned about bottom lines and some of those kinds of things.

As a female union director, she believed that she was "even more attuned to the impact that our decisions are making on people's lives." She eventually surmised that:

Women do have to prove themselves. And you have to either come in and technically prove yourself, or you risk every decision being challenged and questioned. My experience has been once you prove yourself as a technically competent individual, you're not continually challenged on that level.

\section{Crisis Management}

Carol felt that as a union director she does:

more crisis management than day-to-day management. Part of it is because the university really doesn't understand the student union in the sense that the [state university system] created them. Part of 
it's because the campus doesn't have a really strong infrastructure. So, it just seems like everything becomes a crisis before it gets dealt with.

\section{Mentoring/Role Modeling}

Carol did not see herself as a mentor. She recalled that "several students over the years have said, I want to be like you, but I don't know where that comes from." She related this response to her feeling that she isn't "good at giving advice about things."

\section{Future of Women in the Field}

Carol was hopeful that gender "doesn't continue to be a limiting factor." She felt that female union directors should be able to "come to the table as people, not as a gender and be accepted." She advised young women that are considering a career in university union management to:

Be really passionate about what you are doing or the other frustrations are going to become overwhelming. There is a lot of pressure on your personal life. There's a lot of pressure on you to play ball the way the guys play ball.

She recalled instances in which she was excluded from golf outings or happy hours that were organized by male colleagues on campus and even noted that some of her co-worker's wives were suspicious of her interactions with their husbands.

\section{Impact of Career on Personal Life}

In response to the question related to the impact that her career has had on her personal life, Carol's answer was somewhat guarded. She did reveal, however, that she tries to keep her personal and professional lives separate and 
noted, "II think I make the most of the time I do have by choosing who I spend it with and how." She felt that being young and single made her appear more of a threat to female colleagues and limited her ability to establish collegial relationships with male administrators. As a result, Carol has decided to "keep my personal life very much separate from work at this point. So, nobody knows that I'm involved in a relationship and very content with that relationship and not looking to do anything else because I don't bring it to work. I don't involve it at work."

Summary

Carol's lengthy career in higher education administration has included positions in residence life and financial aid. She felt that being a woman did not limit her ability to grow in the field of university union management, yet she provided some significant examples of incidents in which she had been aware of "the fact that I'm a woman playing in a predominantly male world." Single and childless, Carol preferred to keep her professional and personal lives separate and offered few details related to how she spent her time away from her union.

\section{Case Study Four: Donna}

Donna is a Caucasian female in her late fifties who has served as the director of her union for the past six years. She has spent more than thirty-five years at the same campus, having previously held a variety of programming positions before her appointment to the position of Assistant Director of the Union, a position she held for over twenty years. 


\section{$\underline{\text { Role as a Union Director }}$}

In her role as union director, Donna saw herself as "being someone who sets an example and provides a sense of direction for everyone else that works in the organization." She also realized that:

The people that work in that organization look to that individual for motivation and for affirmation and for encouragement and direction, certainly. Someone who can help them define their own place in the organization. Certainly, the focus of what we do in college unions is very service-oriented and I think the director sets a tone for that. In fact, I think the director sets a tone for everything about the operation and how people feel about it.

Surveys and attendance figures have demonstrated that the students on Donna's campus visit the union on average at least once a week. She noted that: As a result, they see their friends there, they do other things there, and so on. And all of that eventually builds into a remembrance of the university. They're much more likely to remember that out-ofclass experience years down the road than they are to remember what went on in the classroom. And, so what we try to do is to help them create that sense of identity.

\section{Description of a Typical Day}

Donna's average day begins at 8 a.m. and frequently includes three or four scheduled meetings. She prefers to handle her own calendar, noting "I'm a great believer in controlling my own time." Most of her days ended by 6 p.m., but "if there is a function in the building or on campus that I need to stay for, a lot of times I just stay on campus. In a given month, I come back for events four 
or five times a month and a lot of these are our own union-sponsored events. Programs, speakers, theatre events and that sort of thing." She tries "very hard" not to take work home with her at night or over the weekend, and notes that she did not have internet access at home. Access to voicemail, she notes, still allows her to remain accessible to her staff, should problems or concerns arise during off-hours.

\section{Education and Training}

Donna entered the field of higher education administration directly out of her undergraduate career. She pointed out that, "There certainly is no academic curriculum that can prepare you for operations. Anybody that I know that does that in this field learns it on the job." She also credited her involvement in ACUI with providing her with the information that she lacked when she moved from a programming position to an operations-based job. She recalled:

The exposure that I had to operations colleagues and attending sessions at ACUI conferences and got to ACUI seminars - that was how I got the exposure to operations. In my own organization, we did not give program people any direct experience in operations. I knew how to draw a room set-up and knew who I needed to contact for audio-visual equipment and those kinds of things, but as far as maintenance and facility up-keep and renovation and all that, that was really through ACUI.

\section{Leadership/Management Style}

Being an "open communicator" and a "good listener" are integral to Donna's leadership style. She remarked that she is "a great believer in positive reinforcement. I think that when you go out of your way to let people know that 
they've done a good job at something, even if it's just part of their ordinary routine, that it really makes a difference in a person's workday." She also believes that professional development opportunities play a key role in the continued growth and satisfaction of her employees. She noted that "when the [travel] dollars are there, I feel that's one of the absolute best ways for people to feel good about their jobs, for one thing, and to learn some new skills and to network with other people who do the same kind of jobs that they do." Donna also reflected, "I also think that it's our job to give opportunity to people. Nobody's perfect. Everybody makes mistakes. It's our opportunity to help those people develop into the best they can be. So I really believe in bringing people along."

\section{Impact of Gender on Ability to Succeed}

Until the late 1990s, Donna was one of only two women to hold a union directorship at higher education institutions in her geographical region. She noted that "all of the men that held these positions were career union people that had probably been in the field twenty-five or thirty years. In fact, some of them had been in the same job that long." Transitions at other regional campuses have resulted in an increase of female directors within the regional consortium of which Donna's school is a member. Deeply engrained social mores are one possible explanation for this slow change, but Donna emphasized that the change certainly has happened slowly in her region. Donna speculated, "I think [this region] has been slower to maybe embrace the idea of women holding certain jobs that were traditionally held by men." She felt that prior interaction with other male directors in her region through ACUI increased her sense of selfconfidence when she began to attend consortium functions after she became a 
director. She admitted, "If I ever felt intimidated by male colleagues or male administrators, it would have been at my own institution."

Mentoring/Role Modeling

Mentoring was significant to Donna and she hoped to model specific qualities that were valuable to her as a union director, including "patience, perspective and persistence." She listed two of her previous supervisors (both men) as individuals she considered to have been her mentors. She remembered her first "boss" fondly, recalling, "He probably had one of the most old fashioned notions of women's place in the world. But, he was a very open person and somebody I could debate with. In fact, he welcomed that."

Feminist Identity

When asked if she considered herself a feminist, Donna responded, "Oh, definitely!" She also noted:

It really bothers me that there's been such a negative connotation attached to that word. When I think of feminism, I just think of women taking the measures and the steps that they need to have the same rights and the same opportunities that our male colleagues have always had. I don't see anything negative about that at all.

Donna felt that the negative stereotypes associated with feminism can be diminished "through dialogue and by talking with young women about what feminism is and what it can be for them. Unfortunately, I don't think a lot of them will really understand until they get out into the workforce." She also observed that: 
Feminism only becomes of interest to women when we run up against those obstacles or those stereotypes. Or, have the experience of being in a mixed group of male and female colleagues and the males only talk to each other because they don't believe that the women have anything intelligent or important to say.

\section{Future for Women in the Field}

Donna observed that she hoped

To see more women go into the operations and business side [of union management]. I think that traditionally, women have been associated with the program side, and rightfully so. I think we're very good at programming. We're good at details and we're good at taking care of people. You know, we tend to have a lot of patience working with students. But, I think there are probably more opportunities for advancement of women who also have experience in facilities and operations and on the business end of it, the accounting and the contact with the lease operators and those kinds of things. And I think that as more women choose to go into business or engineering, or what their choice is, we'll see more people doing that. We'll see more people going into the facilities and operations side. Certainly, there are many more women doing that now than when I started out in the field. You know, that was one of those unspoken expectations...that operations could only be done by men. And, I think we've got some women in the field that have demonstrated very adequately that women can do just as good, if not better, a job in the field. 


\section{Impact of Career on Personal Life}

Donna stated that her career as a union director has impacted her personal life "very positively." She credited the support of her spouse and children as vital to her success, noting that her children were "basically raised in the university environment."

\section{$\underline{\text { Summary }}$}

Donna entered the field of higher education administration when she accepted a temporary appointment to a programming position at her alma mater in the late 1960s. After relocating to another region of the country, she held a number of programming positions at her current institution and eventually became the director of the union six years ago. She has consciously sought out additional education opportunities to strengthen her knowledge base in areas that her expertise was limited (e.g., construction and renovations, operations and facilities management). She has successfully balanced her job and her family responsibilities by establishing boundaries between her work and home lives. Examples of strategies she had adopted included refusing to check email from her home and limiting the number of "after hours" programs that she attended each month.

\section{Case Study Five: Ellen}

Ellen is an Asian American woman in her mid-fifties. For nineteen years she has served as the director of one of the largest university unions in the United States, a facility she describes as "a $\$ 20$ million dollar operation." She has worked on the same campus for more than thirty years and held a variety of 
programming and operations-related positions prior to her appointment to the directorship of the union.

\section{$\underline{\text { Role as a Union Director }}$}

When asked how she views her role as a union director, Ellen noted that her current perception is "a lot different than when I began my career." Upon assuming her position, she thought she would be responsible for managing the facility and its operations. She was surprised to learn, however, that "you're much more externally focused. To protect your building and to be sure that your staff gets the proper information to do their jobs."

This extended focus carries over to Ellen's conception of the rules her staff should play. Ellen encourages her staff members to concentrate on their respective positions during their first year at her union. After that, they are expected to join a committee within student affairs to serve as "ambassadors" for the union. She believed that these networking opportunities allow her staff to "understand that they are part of a bigger team."

Description of a Typical Day

Ellen's average workday is nine hours long and begins routinely with a meeting with her senior staff members. These daily "check-ins" allow Ellen and her employees to "talk about the day. Is there anything unusual or weird coming up? Did anything happen yesterday that we all need to know about?" These meetings last fifteen minutes to an hour and provide critical informationsharing that allows staff members to cover for one another in the event of an emergency or unexpected incident. Ellen noted, "One of the advantages of meeting every day is that we're very responsive. Very few things sit more than twenty-four hours." 


\section{Leadership/Management Style}

Ellen described her leadership style as "orchestrating all the personalities, to be sure that you pull out the best in each of them." She feels that it is extremely important to "be sure that everybody's playing fair." She frequently takes the opportunity to get feedback from her staff:

Because their perspectives are so different and it's important to me. If I'm looking for a real wild, crazy idea or the absolute opposite perspective, I know who I want to go to. If I'm looking for a humanistic interpretation of what's happening around me, I have another staff person to go to or one who's better at it than maybe the others. And then, if I really want an assessment of the political arena, there's another person.

\section{Impact of Gender on Ability to Succeed}

Ultimately, Ellen feels that her ethnicity has impacted her ability to succeed in the field of university union management more than her gender. She observed that being a woman of color has resulted in assumptions being made because "everybody is looking to...I hate to put it this way...fill quotas or look good on an affirmative action report."

\section{Mentoring/Role Modeling}

Ellen considers herself a mentor, especially to her current staff members. She noted, "My goal is for them all to become union directors, so I really try to give them insight into the things I do and to provide developmental opportunities for them on particular projects or delegate responsibilities to them." She has been "pleasantly surprised" to learn that young professionals at other institutions and individuals in other departments on her own campus also 
regard her as a role model, "because that means you can have influence without having a direct supervisory role."

$\underline{\text { Feminist Identity }}$

Although she was hesitant to call herself a feminist, Ellen noted:

I really try to be supportive of women in the field, period. I am really supportive of women and their aspirations and try to encourage them to stretch beyond, further beyond their first inclinations. I think for a lot of women, their first inclination is to hide.

Future of Women in the Field

Ellen's vision of the future included "more women union directors, obviously." She hoped that women "have the confidence to push themselves. Get out there and do it." More importantly, however, she would like to know that individuals that aspire to become union directors

are happy. And that it's less a gender thing then that they are happy doing what they're doing. And that they feel satisfied with that. If they want to have a family and that's where they want to focus, that's where they focus. If they want to be a union director, that's fine, too.

\section{Impact of Career on Personal Life}

Ellen and her spouse have worked together to raise their child. Her husband even spent time as a stay-at-home dad until their youngster was old enough to begin kindergarten. When her husband began to work on-campus as well, their child regularly spent time at the union and even helped Ellen's student workers with room set-ups and attended events and activities. She 
fondly recalled that when the toddler was four, she requested a Christmas "wish list" from the youngster. She was thrilled when her child simply responded, "I want the union."

Summary

Ellen's career path to a union directorship included four different programming positions on two different campuses and lasted approximately thirteen years. She credited the support of a former director in her decision to pursue a union director job for herself and learned many of the operational aspects of her position by serving as an assistant director first. Despite her professional accomplishments, she admitted that the most important goal in her life was to be "a good mother" and acknowledged that she "wasn't always there" for her family. Her felt that her child was "really very much a part of the union" because the youngster frequently accompanied her to work and would sometimes disappear "for three or four hours" to help her student employees set up for programs or events that were held in the facility.

\section{Case Study Six: Faith}

Faith is a Caucasian female in her early fifties. She worked in the college union field for twenty-five years. She left the field in the late 1990s after serving as the director of a union facility located on the campus of a large, state university.

$\underline{\text { Role as a Union Director/Description of a Typical Day }}$

Faith recalled, "One of the things that surprised me when I became the director of a union was that I spent more time in the political arena than I did 
working with staff, students and as directly with operations as I did before." Her average day began at 7:30 a.m. and regularly spanned twelve to fourteen hours. She remembered:

The office support folks would hand me my schedule for the day, which typically consisted of nine hours of meetings. Lunch was spent in a meeting with someone...meeting and eating. At five or five-thirty in the afternoon, when most people went home, I stayed to follow-up on the things I didn't have time to do during the nine hours I was busy talking to folks. I'd try and take what I had done in the meetings and translate it into action, either my own or some else's. It was nine-thirty or ten o' clock just about every night before I went home.

She also felt that this demanding work schedule was mandated by her vice president and recalled "He worked eighty to ninety hours a week and expected that everyone that reported to him do the same or they were not worthy." Single and childless, she noted that, "I didn't have things that were tugging at me. It was easy for me to dedicate my time and my efforts toward that particular job, even though I didn't like that. There was a job to be done and one of the things I've always done my entire life is, if there was a job to be done, I did it."

Her workaholic lifestyle was not expected of her staff, however. When asked about this issue, Faith quickly responded, "I don't like to put people in that situation. I worked in a community where there was lots to do and I encouraged folks to have that balance." 


\section{Leadership/Management Style}

Describing her leadership style as "situational," Faith stated that it was "based upon what the outcomes need to be. I've always been perceived as someone who is expecting as much from others as I was willing to give in terms of quality service. Some people needed more structure than others and I would provide that for those who needed it." She admitted that there were some differences between her managerial style and that of her male colleagues, but also noted that:

I tend to be very direct and to the point and my style is more typically viewed as one that males portray more than women. There's not a lot of emotion that gets into the mix and I'm very task-oriented and outcome-oriented and not typically labeled as high relationship, even though I have very solid relationships with people. It's not the stereotypical female process. Mine is much more analytical.

\section{Impact of Gender on Ability to Succeed}

Faith definitely felt that her gender had impacted her ability to succeed in the field of university union management. She states that she "had to work harder at it than my male counterparts. I had to prove myself. The expectation was greater from my male supervisors." She also pointed out that none of her direct supervisors had been women.

Faith looked to other women in similar positions as mentors. Typically she developed relationships with colleagues on other campuses and "looked to them for support." She admired the sense of balance that they appeared to have between their professional and personal lives. She stated that, "They had 
something else besides the job. I was always looking for ways that I could walk away from the job at five o'clock or six o'clock, but I didn't have that same situation."

\section{Crisis Management}

When a natural disaster decimated her former facility, Faith's initial reaction was, "Holy cow! Look at all this task! It was like triage. What do we need to do first?" More difficult than organizing the recovery and rebuilding projects, however, was the "politics that went along with that, and the abuse. Not just to me or to the people in the union, but to the entire campus. Because our leader, our president, demanded so much. The humanity of the campus was not considered in this." She still felt that the tremendous loss that was experienced by the entire campus was never acknowledged. She noted:

It's not a matter of work, it's a matter of what's the impact on the human soul. We can't not take that into account. People have to grieve. Whether you lost the files in your office, or the place you normally work is now gone and you have to rebuild that, it's a huge loss for people. That was a missing element.

\section{Feminist Identity}

Faith hesitantly described her as a feminist "from the standpoint that I've always tried to pave a way for others after me. There's a lot of very capable young women and I'll do anything I can to help them be successful." She was concerned, however, that a "gap" exists between the veteran female union directors and the young female professionals that could potentially succeed them as they retire. She asked, "Where are the people to follow them?" 
Future for Women in the Field

Even though she left her directorship four years ago, Faith's perspective for the future of women in the field of university union management was similar to the response given by Ellen. Faith hoped:

To see more and more women be attracted to the profession where they will be happy and they will be adequately compensated. If women aspire to be directors of unions or vice presidents or presidents, we should do everything we can to support that goal. I think in general, that women tend not to want to work all the time. Women have a tendency to find success and achievement differently than men do. So, I wouldn't impose a view of success on women and say that women haven't gotten where they wanted to go because of their gender.

\section{Impact of Career on Personal Life}

After leaving her last position, Faith began working with a non-profit organization that supports administrators in higher education settings. When asked if she had any regrets, Faith immediately answered:

No. I had said at one point in my career that I never wanted to do anything else. I just loved being in the union. I loved working with students. I loved working with diverse populations. I loved doing the work and thought that I would never leave it. I'm the person that I am because of those experiences. But, I have absolutely no desire to go back to work on a campus.

She also felt that her latest career path allowed her to serve the same community without "huge politics" and "huge egos." 


\section{Summary}

Faith entered the field of university union management because she "needed a job." Unlike many of the other women included in the study, however, she never held a programming position and was able to obtain her first directorship position after having held three other operations-related jobs at three different institutions. She was challenged by the political responsibilities associated with her directorship role as well as the limited amount of time she was able to spend on the operational needs of the facility. Single and childless, Faith confessed that she was a workaholic and spent sixty to seventy hours a week at her union. She looked to colleagues with families as examples of how she could better balance her job and her personal life.

\section{Case Study Seven: Gwen}

\section{$\underline{\text { Role as a Union Director }}$}

Married and in her early forties, Gwen is a Caucasian female who manages the university union on a large, public campus that measures more than 300,000 square feet. She sees her role as the director of the facility as "multifaceted," and enjoys her ability to interact with students as well as the opportunity to "manage" university politics (even though one of her least favorite aspects of her job is the "constant political battles and competition for funds").

\section{Description of a Typical Day}

Gwen's typical day begins at 7:30 a.m. and lasts twelve hours. During this time, she "responds to different incidents," attends a variety of meetings, events 
and activities and is faced with innumerable personnel and budget decisions. She credited the support of her husband with her ability to work extended hours and sometimes hires a student to baby-sit so that she and her spouse can go out "every couple of weeks."

\section{Impact of Gender on Ability to Succeed}

Gwen insisted that she has refused to allow her gender to impact her ability to succeed as a university union director. When asked about this issue, she simply responded, "I haven't let it." When asked to share her views regarding gender equity for female union directors, she noted:

Salaries are still below those of males. It's getting better, but it seems that most of the men offer to assist, consult, mentor and are offended if you don't ask for their help. There seems to be a lot of ego involvement for men vs. women. I definitely don't feel like I'm part of "the club." My associate director (who is male), constantly gets approached and asked questions about our union. I get very few questions, let alone acknowledgement that I' $m$ the director.

\section{Mentoring/Role Modeling}

Gwen struggled to name individuals that she considered to be her mentors, noting that all of her role models have been men. Despite this experience, she viewed herself as a mentor for her staff and students. She stated that, "I always focus on how I can help my staff grow personally and professionally. I spend a lot of time advising students and allow them to make their own decisions and mistakes." She was also hopeful that there will be more female union directors in the future and encourages young women to "be openminded and learn as much as you can." 
Impact of Career on Personal Life

Overall, Gwen felt that her career choice has been a positive influence on her personal life. She observed that her work has, "made me a stronger, more confident person. It has forced me to be more organized, professionally and personally."

Summary

Gwen became involved in university union management when she worked at her campus union during her years as an undergraduate student. Prior to obtain her current directorship (which she has held for four years), all of her work experience had been in operations-related positions. While her career as a union director has had a positive impact on her life, Gwen still felt that she wasn't part of the "club" established by male union directors. In spite of her hectic schedule, Gwen has successfully managed to balance her career with her roles as a wife and mother.

\section{Case Study Eight: Helen}

Helen is a Caucasian woman in her late forties. She has served as the director of her union for nearly five years. Measuring over 180,000 square feet, her facility is located on a large, urban campus. Helen particularly enjoys "working with the students, the challenges and the rewards. It's a great job! Next is the facility operations. The ability to take the facility, bricks and mortar and translate that facility into a community center is an awesome opportunity." She least enjoys "the politics...the games you have to play to get the job done or to meet your goals." 


\section{$\underline{\text { Role as a Union Director }}$}

Helen views her role as a union director as "multifaceted in terms of running a facility and providing leadership and vision. Setting the big picture. Setting the future direction of where our organization is going to go." She reluctantly admitted, "As much as my heart is in the day-to-day activities, I don't spend a whole lot of time there anymore because I have bigger things to position and to learn to be a political navigator for our organization."

\section{Description of a Typical Day}

While she described herself as a "recovering workaholic," Helen's average day workday still begins at 7 a.m. and she typically works fifty-five hours a week. She "occasionally" takes work home, but tries to limit herself to "only one project at a time."

\section{Leadership/Management Style}

Helen replaced a male director that had been at her institution for more than twenty-five years. Her staff members have told her that they appreciate the differences in her managerial style and the changes she has made since her arrival. She declared, "I think women focus more and more on getting students involved and out in front. And that's what makes the students grow and the union grow and it's a slightly different style."

Utilizing an open-door policy, Helen let her students and staff know that they can talk to her about anything. She was told, however, that she "scared the hell out of the students." In response, she created a student management team, hoping that, "if they won't talk to me, they'll talk to their peers." She meets with this group of student employees once a month to work on issues, including getting feedback from students on their recently developed strategic plan. 
Mentoring/Role Modeling

Mentoring students and young professionals is important to Helen. She enjoyed "preparing people to grow beyond what they think they can do. Being supportive and challenging." Helen also noted, "I never settle for status quo and I urge people to push the envelope all the time. If we falter, it is okay to get up, dust ourselves off and more forward again, learning from what tripped us up in the beginning. More importantly, I believe in ethical decision-making and integrity. An that is what I try to convey to people that work with me."

In addition to her ability to mentor students and young professionals that hope to enter the university union field, Helen also serves as an educator on her campus for issues of diversity, tolerance and respect. After she was nearly "outted" by a student organization at her former campus, she regularly discusses her sexual orientation at staff training sessions in an effort to educate others. And, while she noted that she preferred to "make my point and bring people along," she admitted that serving as a role model was "a great teaching tool." Feminist Identity

Helen was fairly decisive in her response that she did not consider herself a feminist. She stated, "I don't really consider myself a feminist. I believe in women's issues and women's rights, but I believe in all rights. And, I will fight equally hard for anyone that is being mistreated."

\section{Future of Women in the Field}

Helen was especially optimistic about the future of women in the field of university union management and sees:

More and more of us being presidents of universities. I really do

think that is going to happen because more and more people have 
got to realize the impact that student affairs has and the union and activities folks have on the life of the campus.

She realized, however, that her views might be:

Idealistic and unrealistic because the academic side may not, or try not, to let that happen. But, I really think that there's going to be more and more of us moving up higher, out of union work directly into vice presidencies.

\section{Impact of Career on Personal Life}

Helen valued the support of her partner and noted that, "I've been told that, for a gay couple, we live more like a traditional married couple." In fact, her partner left her business and relocated to another region of the country when Helen was offered her current position. And while her partner has slowly reestablished her business, Helen is definitely the primary breadwinner in their

household. Renovating their home and a menagerie of pets provide a source of balance for Helen. She also played golf in a local league that included other women from numerous area businesses, noting "it's making connections and knowing what's going on in the community."

\section{Summary}

Helen held various programming positions with a community-based nonprofit organization prior to her entry into the field of university union management. She relocated to another region of the country to accept her current directorship (which she has held for four years). She felt that a lot of "old school administrators" in higher education administration (though not necessarily in union management) were in the position to impact the ability of women to succeed in the field by influencing hiring decisions on some campuses. 
Helen described herself as a "recovering workaholic" and tried to limit herself to taking only one project home to work on each night. She played golf in a women's league comprised of local businesswomen and has established a fitness regimen with her partner to provide a sense of balance between her career and her personal life.

\section{Case Study Nine: Iris}

Iris could be considered the "rookie" among all of the women included in the study, having held her directorship for less than one year. An Asian American woman of color in her early forties, she enjoys the constant challenges of union operations and working with a diverse campus population. She acknowledged, however, that the politics related to her position can be "extremely challenging" and noted, ""While I like to think of myself as very accommodating and eager to please, it is not easy to say yes to everyone's requests and it can be very difficult saying no to student leaders."

\section{$\underline{\text { Role as a Union Director }}$}

Iris feels that her role as a union director is to "maintain the student union so that it is seen as a viable place for students in the campus community. Provide facilities and services that students want and that the campus community can use." She is concerned over the maintenance and upkeep of the union, as the facility is more than thirty years old and no longer meets the needs of the institution's current student population.

A proposed referendum to increase student fees to provide for a new university union did not pass. As a result, one of her primary goals is to 
"revitalize" the existing structure with the limited funds available to her. Potential projects included replacing carpeting and paint in meeting rooms, identifying new vendors to lease available retail spaces in the facility and purchasing state-of-the-art audio visual equipment for use by student organizations and conference groups.

\section{Description of a Typical Day}

Iris noted that she usually arrives at her office at 7:00 a.m. First, she checks her email and voicemail for any new messages. Then, she walks through the building and meets with her building services manager and receives updates related to needed repairs or anticipated projects.

Although her daily schedule contained an average of four "back-to-back meetings," Iris attempts to "block off" two to three hours of time each day to tackle paperwork, return phone calls and email messages. She remarked that, "at least people know that I'm accessible during those times."

Iris declared that she probably works ten to twelve hours a day. She preferred to stay at her office rather than take work home with her. Iris stated:

Usually by the end of the day, I'm so brain-dead and fried that I'm not effective at home. I try really hard to keep my work life and home life separate. If I bring anything home, it's something that I have to read or proof, or I'm reviewing notes for a presentation I have to give the next day. But, for me to hop on my computer at home and start doing work...no, because in order for me to keep my sanity, my home life is my home life and I just don't want to cross that line. 


\section{Leadership/Management Style}

Iris described her management style as "simple." She feels that the documentation of incidents and meetings is also critical and plays an important part in her ability to remain communicative. Teamwork is also significant to her and she tried to involve her staff in decision-making, whenever possible.

Iris laughingly referred to herself as "borderline overly anal-retentive." She feels that her leadership style differed from that of her male colleagues in that she tried to be "really, really detail oriented," while she characterized previous male supervisors as "ambiguous and vague." She noted that her directions to her subordinates are "very specific, " but she felt that she still allowed for "freedom and flexibility" for her staff to provide feedback and input. Overall, Iris was committed to "bring people together as a team. "

\section{Mentoring Relationships}

All of Iris' supervisors in the field of university union management have been men. She noted that the most influential individual in her career development had been a woman that she worked with prior to her entry into the field. Iris remembered:

She was very approachable, she was very communicative, she had a great sense of humor. If you made a mistake, she never made you feel bad about it. I think I learned a lot from her. And, I think I've integrated a lot of her management style into who I am today. Iris encouraged young women considering a career as a union director to: Work hard and persevere. Get a lot of practical experience. Work hard and go above and beyond what your current job is. Try and get a mentor. Find somebody that you can click with and connect 
with and someone that's going to work with you and help you along.

As far as her three previous male supervisors were concerned, Iris felt that:

In retrospect, if I look at them, I've learned something from each one. Not purposefully as a mentor/mentee type of relationship, but I've learned about management styles that work, definitely management styles that don't work, how I do not want to manage. Communication styles that I just thought were inappropriate. So, in that respect, I don' $t^{\prime}$ know if you can look at that as a mentoring relationship, but it's more like lessons learned from previous supervisors.

\section{Impact of Gender on Ability to Succeed}

Iris has never felt that her gender impacted her ability to succeed in the field of university union management until she had been in the field for almost a decade and began to work with a new male supervisor. She noted, "I was pretty much shocked at how different I was treated as opposed to my male counterparts, who were in lower positions that I was in. There was a lot of favoritism towards the males and I was pretty much excluded. I was the assistant director and my supervisor was the director, but did not treat me as such. It was quite noticeable to me, to the staff and to outside people.

Like Ellen, Iris considers her ethnicity to have been more significant in her ability to obtain a union directorship. Iris expressed her concern that because she was a woman of color that people have looked at her and thought, "she fills an affirmative action quota." She has shared her fears with her previous and 
current supervisors and was assured that was not the case and that in fact, she was the top candidate for her position. Despite this reassurance, however, she admitted that this negative perception, "still bothers me."

\section{Education and Training}

Following graduation from high school, Iris began working in the hotel/restaurant industry and did not consider going to college. To appease her parents, she began coursework at a local university, but as a commuter student, she never felt connected to the campus and subsequently left school to work fulltime. While she has continued to intermittently take classes, she has not completed her undergraduate degree. Iris admitted that she is an anomaly in the field of university union management, as the majority of her counterparts at other campuses typically have a master's degree.

Iris eventually applied for a meeting services coordinator position at a large, public university and began to appreciate the sense of flexibility and excitement that the union environment offered. Three years later, she was encouraged to apply for the assistant directorship of a union on another campus. She successfully obtained that position and served in that capacity for nearly a decade. When her supervisor (the director of the union) retired, Iris served as the interim director for almost a year. She recently left that institution to accept her current position (union director) at another large, urban campus.

Iris remarked:

When I first entered the university union business, going to meetings and conferences was very disconcerting because people automatically assumed you had a degree. And so when people would ask me, where did you go to school, I'd tell them, oh, I went 
to [name of institution]. And then I sometimes kind of felt like I needed to be honest and say, well I never graduated. At first I was say that, I never finished. And then the question became where did you get your master's? And when I would give out, well I never really finished my undergrad, people were always really kind of shocked by that.

When asked if she felt that college coursework that she did complete had prepared her for her career as a union director, Iris responded, "No. Not a lick." She noted that she was "a very tactile learner. Just practical experience, being hands-on, learning as much as I can, being hands-on is really what has prepared me." She also believed that even if she had finished her undergraduate program, "there's no way that it would have prepared me for this job."

\section{Mentoring and Role Modeling}

Iris fondly recalled a former student employee that she still maintained a relationship with and noted:

She said that our conversations and the advice I had given her through the years had influenced her life. She told me she appreciated the fact that even in her lowest time, I never judged her or made her feel bad. She always felt that she had my undivided attention.

It wasn't until that moment that Iris was able to realize "what an impact you can have on someone."

\section{Feminist Identity}

When asked if she considered herself a feminist, Iris emphatically responded, "Oh God! No!" She noted that the term held negative connotations 
for her. She stated, "I look at it as...when people are looking to recruit people for a job, don't look at the gender or the ethnicity...hire the person that is most qualified, the best fit for your organization."

\section{Future of Women in the Field}

Iris hoped that "women continue to be a strong force" in the field of university union management. She was happy to see that "women have progressed and been able to get the positions, as far as the assistant directors, associate directors and union directors are concerned. I just hope that continues." She attributed the formative management style exhibited by the majority of the female union directors she had observed as significant to the success of women in the profession. She remarked, "Women are very organized, they're detail-oriented, they communicate better and women tend to be more warm and fuzzy as opposed to men."

\section{Impact of Career on Personal Life}

Iris looked to her family, her boyfriend and "a great group of friends" for support. She noted that her parents "really didn't understand" her role as union director, "they just know that I work at the university and I have this director title. They're so proud. But, I don't think they really have a true understanding of what it is I do."

Iris realized early in her career in university union management "that you just can't do it all." Gardening, travel and volunteering time with a local community agency have allowed her to develop a sense of balance and separation between her personal and professional lives. 


\section{Summary}

Iris had worked in the hotel industry prior to her entry into the field of university union management. She held two operations-related positions prior to her appointment as director at her current institution less than a year ago. Iris felt that the impact of her gender on her ability to succeed in the field was limited, however, she was concerned that colleagues would feel that she was hired because of her ethnicity. Iris refused to take work home with her at night and relied on her staff members to respond to after-hours situations at her union in an effort to establish boundaries between her work life and her home life.

\section{Cross Case Analysis}

The cross case analysis conducted in conjunction with this research project grouped together the subjects' responses to questions included on the participant profile and asked during the interview sessions. This technique was effective in formulating both a collective sense of the experiences of the nine female union directors included in the research sample and advanced answers to the three research questions related to the impact of gender on the research subjects' ability to obtain directorship positions, succeed in the field of university union management and effectively balance their careers with their personal lives. This discussion of the cross case analysis begins by considering these three topics and then examines some other related issues that emerged when the nine cases were considered as a group. 


\section{The Effect of Gender on the Ability to Obtain a Directorship}

The majority of the respondents indicated that their gender had, little, if any, effect of their ability to obtain a position as a university union director. The lack of available directorships (due to the pattern of longevity in such positions established by veteran male directors), perceived lack of competencies or skill sets applicable to the operational aspects of the union management field and poor self-image in comparison to other (male) candidates for open jobs were some of the examples given by participants as potential barriers that limited their access to directorship positions. Each of these factors will be discussed below. The Longevity Factor

Of the three factors cited in the previous paragraph, the most obvious one relates to the pattern of longevity in the position. Clearly, one reason it took longer for women to be hired in union director positions once women became viable parts of the labor force is because these positions were already occupied by men and, once a person holds a union director position, that person is likely to hold it for a long time. The most recent ACUI salary survey (ACUI, 2003) noted that the average number of years that male union directors had held their positions was 9.2. The average number of years that the female directors included in the study had held their positions was 6.9 (ACUI, 2003, p. 26).

Although the average number of years that the women featured in this study have spent in their current positions is 7.7, two individuals included in the sample for this study have served as the directors of their unions for 19 years, each and one has served for 10 years. While several of the women were looking for career options after the union directorship, this sort of career progression has 
not been commonplace in the past and was not part of thinking of the majority of the women in the study. Thus, the source of the "glass ceiling" here - at least in the past - may have been in the position itself, rather than gender bias. Because the position traditionally been a terminal position rather than a stepping stone to a "bigger and better" position, people have remained in this position for long periods of time and blocked others - including women - from getting these jobs.

The lack of openings - rather than direct gender bias - may be the reason for the long and arduous career paths to the union directorships observed in this study. The respondents for this study had held a variety of positions within university union management and student activities prior to obtaining their respective directorships. Examples of previous job titles included: programming advisor, resident assistant, scheduling coordinator and assistant director of operations. These positions are indicative of the variety of work experiences that union directors may have during their working lifetimes.

The nine women included in this study in fact, had 204 years of combined experience in higher education administration. The average number of years in the field is 22.6. The greatest number of years spent in the field of higher education administration by one of the participants is 36 . The lowest number of years is 12 . A review of the data related to longevity in the field is demonstrated in Table 1. 
Table 1

Comparison of Data Related to Longevity in the Union Management Field

\begin{tabular}{|l|c|c|c|c|c|c|c|c|c|}
\hline & Ann & Barbara & Carol & Donna & Ellen & Faith & Gwen & Helen & Iris \\
\hline $\begin{array}{l}\text { Years in } \\
\text { the } \\
\text { Field }\end{array}$ & 23 & 22 & 17 & 36 & 32 & $25^{*}$ & 22 & 15 & 12 \\
\hline $\begin{array}{l}\text { Years as } \\
\text { Director }\end{array}$ & 15 & 19 & 5 & 6 & 19 & 4 & 8 & 4 & $1^{\text {** }}$ \\
\hline $\begin{array}{l}\text { Years in } \\
\text { Current } \\
\text { Position }\end{array}$ & 10 & 19 & 3 & 6 & 19 & 4 & 4 & 4 & $1^{\text {** }}$ \\
\hline
\end{tabular}

*Left the field in 1999

**Has held directorship for less than one year

These findings are consistent with those reported by Swanka (1998) and generated through her survey of 37 female union directors in the United States. Her results indicated that the majority of female union directors had been in the field for more than ten years. More than half of her participants had been at their current institutions for more than 10 years (Swanka, 1998, p. 17). Because her focus was almost exclusively on the career paths women took on their way to union directorships, however, Swanka did not attempt to make sense of the rather elongated career paths she documented and, therefore, did not identify longevity in the position as a likely explanation for the length of time associated with acquiring the position.

The years of experience needed to achieve a union directorship is also reflected in the average age of the participants, which is 48.4 years. The oldest individual included in the sample is 59 . The youngest is 39 years old.

As a result of the anticipated retirement of male administrators, union directorships currently held by men will become available to young 
professionals who aspire to hold a leadership position in the field of university union management. The sample assembled for this study is representative of both the insurgence of young professionals and the "graying" of union directors that will result in the retirement of many of the field's seasoned veterans. At least two of the women included in this study obtained their positions when the previous (male) directors retired. One of the participants recently announced her own retirement and is considering her future as a consultant or instructor in a higher education administration program.

The responses by the participants also suggest that a union directorship is now at least being thought of as a stepping stone for women who are interested in pursuing upper level administrative positions in higher education. One of the respondents had already applied for an associate vice president position on her campus. Another participant was completing a doctoral program and a third member of the sample was considering enrollment in a terminal degree program.

The Competencies and Skills Factor

A number of women spoke of their lack of competencies and skill sets, especially with respect to handling the operational as apposed to the interpersonal aspects of union management and one could infer that this insight might be another reason why certain women might not ever apply for union director positions, or, if they apply, why search committees might see a female applicant as less than qualified. Not surprisingly, therefore, education and training were extremely important to all of the participants. Seven of the respondents held a master's degree and one was enrolled in a doctoral program dedicated to the study of organizational leadership. One of the women held a 
bachelor's degree and one has completed some college coursework, but had not finished a degree program. All of the women with master's degrees felt that their various graduate programs have prepared them for their respective careers in university union management, particularly in the areas of accounting/budgeting and personnel management. A comparison of the educational background of the respondents has been compiled in Table 2 .

Table 2

Comparison of the Educational Backgrounds of Respondents

\begin{tabular}{|l|c|c|c|c|c|c|c|c|c|}
\hline & Ann & Barbara & Carol & Donna & Ellen & Faith & Gwen & Helen & Iris \\
\hline $\begin{array}{l}\text { High School } \\
\text { Diploma }\end{array}$ & $\mathrm{XX}$ & $\mathrm{XX}$ & $\mathrm{XX}$ & $\mathrm{XX}$ & $\mathrm{XX}$ & $\mathrm{XX}$ & $\mathrm{XX}$ & $\mathrm{XX}$ & $\mathrm{XX}$ \\
\hline $\begin{array}{l}\text { Undergraduate } \\
\text { Degree }\end{array}$ & B.A. & B.A. & B.S. & B.S. & B.A. & B.A. & B.A. & BS & --- \\
\hline $\begin{array}{l}\text { Master's } \\
\text { Degree }\end{array}$ & M.A. & M.A. & M.A. & -- & M.A. & M.S. & M.A. & M.A. & -- \\
\hline Doctorate & --- & --- & $* * *$ & --- & -- & -- & --- & --- & $\cdots$ \\
\hline
\end{tabular}

${ }^{* * *}$ In progress

Even though all of those interviewed valued formal training, all also acknowledged that many of the responsibilities associated with union directorship positions can only be learned through practical experience. Examples included crisis management, construction and renovation, program planning and mentoring. The majority of the respondents stressed the importance of extended learning opportunities offered by professional organizations. They also indicated they utilized on-the-job experiences (such as construction and renovation projects) to ask questions and gather additional information. Overall, respondents encouraged female students who may be 
considering union management as a career option to diversify their academic and work experiences in order to produce well-rounded, multitalented young professionals.

As the only participant without a college degree, Iris was atypical in comparison to the eight other women included in the sample created for this study. Her ability to obtain a union directorship at a large, high-profile institution demonstrated that it was still possible to attain a directorship position based primarily on previous work experience and professional reputation.

The respondent's commitment to education and their own educational backgrounds coincide with previous studies (Blackburn, 1989; Milani, Johnston \& Brittain, 1992; Morton, 1999) that suggest that the recent wave of retirements, larger staffing patterns and concern related to the attrition of staff will ultimately "create new demands for career preparation in the field" (Morton, 2003, p. 45). These results are also similar to those found in Swanka's (1997) study that indicated that female union directors are more highly educated than those included in studies conducted in the 1970s and 1980s (Clay \& McMillan, 1974; Delahunty, 1986).

While the female directors interviewed for this study felt that a combination of their education and practical experience has ultimately prepared them for their careers in university union management, they also acknowledged that the lack of standardization of curriculums offered through college degree programs (in higher education administration, college student services, counseling, etc.) could result in inadequate and inconsistent preparation for aspiring professionals. These observations were echoed by Ratcliffe (1998) whose assessment of trends and concerns in the field of university union 
management indicated that few college degree programs are designed to prepare college union personnel and fail to prepare union professionals for what may be considered "essential functions of directorship positions, including budget management, facilities and operations management and event planning and services" (Ratcliffe, 1998, p. 24).

\section{The Poor Self Image Factor}

Some of the women in the study suggested a third factor that might explain the limited number of women in union director positions in the past. This factor could also limit the number of women who apply for director positions now that such positions are opening up. The factor involves low selfesteem and poor self-image with respect to meeting the demands of a demanding position. Donna, for example, had thought about applying for the directorship of her union when her boss retired in the mid-1980s. She noted, "I would have loved to have thrown my hat in the ring for that position at the time, but I didn't because my children were just starting elementary school at the time and I really didn't think I could manage that." Helen had been encouraged to apply for an associate vice president position on her campus by the vice president of student affairs. She admitted that she "turned it down because I didn't think I was ready."

Two points need to be made about this third factor. First, this third factor suggests that gender bias may be more of a factor here than the women in the study understand or acknowledge, to the extent that women, because of society's socialization, do not think of themselves as being capable of taking on the role of union director and do not even apply for such positions. Gender bias may, 
indeed, be operating here, albeit in an indirect (and even clandestine) manner, rather than a direct way.

Second, this third factor provides another perspective on why education may be important for women: an advanced degree may matter as much for the status and credentials it confers (independent of any skills or knowledge it actually provides) as for what is actually learned in a degree program. This analysis is certainly consistent with what was found in the literature review and reported in Chapter Two about women's greater reliance on formal credentials rather than personal relationships or networks as sources of career advancement (Fox, 1989). This analysis, however, also extends the ideas found in the literature by suggesting that credentials may have an intrapersonal benefit as well as the benefit of enhancing a candidate's viability in the eyes of a search committee.

\section{Impact of Gender on the Ability to Succeed in the Field}

The female union directors that participated in this study all felt that their gender has a greater effect on their ability to succeed in the field than their ability to actually obtain a directorship position. One respondent commented that, despite her longevity in the field, she still did not feel like she was a member of the "club." Other women noted that they felt that their abilities were constantly questioned or dismissed because of their gender. The ability of at least some of the interviewees to begin to establish their own pattern of longevity in a field dominated by white males, however, indicates that women are able to be at least somewhat successful in overcoming (or at least circumventing) the on-the-job 
gender bias the women perceive. All the women, in fact, indicated that they truly enjoyed their jobs.

This section of the cross case analysis reviews data related to the following topics: salary issues, sources of frustration, leadership styles as an explanation for perceived gender discrimination and sources of satisfaction and support for women in union director positions.

\section{$\underline{\text { Salary Issues }}$}

One traditional indicator of gender discrimination is salary differences between men and women. Historically, such differences existed in the field of university union management. Such differences were not especially evident in this study.

The average salary for the women participating in this study was $\$ 84,986.25$. The highest individual salary received by one of the respondents was $\$ 111,000.00$. Two of the participants reported receiving the lowest salaries for the group; $\$ 69,000.00$ each. These results are significantly higher than the average salary data gathered by Swanka (1998) that indicated that the average salary for female union directors was $\$ 55,083.00$.

A number of factors can explain this variation. First, five years have passed and incremental salary increases have been initiated for most positions within the field of university union management. ACUI annual salary surveys report average increases of three to four percent per year. Second, as previously noted, all of the women interviewed for this study are employed at fairly large, public, four-year institutions. Third, Swanka's larger sample was more geographically diverse. The geographical location of the facilities of each of the respondents in this study are in urban locales and the high costs of living 
associated with these areas also undoubtedly impact the level of salaries received. Swanka's study included a greater number of participants and undoubtedly included data from union directors from a wider variety of campuses.

Thus, for the women in this study, salary differences did not seem to be a problem. Rather, on-the-job gender discrimination took more subtle and less obvious forms. Yet, the exact nature of discrimination was difficult to pinpoint even when women talked about their on-the-job frustrations.

\section{$\underline{\text { Sources of Frustration }}$}

Although a number of interviewees complained about not being taken as seriously as they believed their male counterparts were, most of the actual problems they articulated seemed to have less to do with gender than with the nature of the role they played and the political environment of the universities in which they worked. For instance, the responses provided by the participants suggest that union directors struggle with the fact that their positions are seen as middle management positions. The participants also indicated a sense of frustration over the lack of respect given to the unions and their staff members as well as the limited understanding of the directors' responsibilities by other members of the campus communities (i.e., administrators, faculty and students). The political roles that the female directors assume on their respective campuses are clearly seen as a means to change this perception and elevate the overall image of the union from "the fun house" to a facility that serves as a place for learning, in addition to the traditional classroom setting.

It was apparent, in fact, that most of the women included in the study were somewhat frustrated by the politics that were connected with their 
positions. Respondents complained that the time required to resolve politicallycharged issues prevented the respondents from pursuing activities they found to be more useful and enjoyable, including interacting with students and staff and conducting regular "walk throughs" of their respective facilities.

While the political aspects of their positions were viewed as some of the least desirable parts of the job, the respondents' answers suggest that they recognized the importance of political work. Whether their distaste for such work was gender-related - whether, in other words, their male counterparts found the politics of the job equally distasteful - could not be answered in this study.

\section{Leadership Style as an Explanation for Perceived Gender Discrimination}

It is possible that one explanation for why women perceived on-the-job discrimination -- but the sources of such discrimination were so difficult to pinpoint -- relates to the women's leadership style. The descriptions provided by each of the subjects related to their individual leadership/management styles were reminiscent of those identified in previous studies (Astin \& Leland, 1991; Clark, Caffarella \& Ingram, 1998; Clark, Caffarella \& Ingram, 1999; Dailey, 1991; McKenna, 1997; Schaef, 1992). These women considered themselves to be participatory, collaborative, inclusive and empowering in their approaches to leadership. Staff members under their supervision were encouraged to work autonomously and provide their own visions for their respective work areas.

It is important to note, however, that virtually all of the women in this study did not feel that their individual leadership styles were indicative of their gender. They noted that many of these same methods were also practiced by 
their male colleagues and were more readily associated with student affairs practitioners, in general.

One area where there may be difference is the personnel management area. The concept of "splitting" described by Snee (1994) was suggested by the responses of the female directors who struggled to separate their personal feelings from personnel issues. The majority of the respondents placed greater weight on incidents that involved the termination or discipline of staff members than surviving a natural disaster, and suggested the psychological impact of their supervisory responsibilities. Again, it must be noted that the question of whether men would think and act differently in the personnel area is beyond the scope of this study.

\section{Sources of Satisfaction and Support}

Thus, it has been difficult to pinpoint in this cross case analysis the precise way that gender discrimination has impacted the interviewees on-the-job activities despite the claims of many interviewees that it, in fact, has had such an impact. What is evident from the data, however, are clear sources of satisfaction as well as obvious sources of support.

Included on the satisfaction index is the power union directors had on their campuses. The data collected from the participants revealed that as union directors, they had a tremendous amount of power within their campus communities. They were responsible for large, multipurpose facilities and oversaw budgets worth tens of millions of dollars. The responses provided by the women included in this study suggested that they were proud of their ability to create and project visions for the future of their various facilities. These answers, however, were never overtly egotistical or self-aggrandizing. 
The majority of the women included in this study were able to identify men and women in the field of university union management that they considered to be mentors or role models. Those that were able to identify their mentors attributed that relationship to their ability to achieve their current position. All of the women noted that they had colleagues (primarily at other campuses) that they turned to for encouragement, support and feedback. Although previous studies (Durnovo, 1990) have found that mentoring can be associated with individuals' abilities to obtain upper-level administrative positions, the majority of the women in this study have clearly achieved success without the benefit of a true mentoring relationship.

The majority of the participants also clearly valued their ability to serve as mentors to their students and staff. In addition to modeling professional behavior, the respondents also felt that they were able to provide additional resources to allow their students and employees to learn more about union management and grow as professionals. Examples included funding for conference registrations, enrollment in workshops and seminars and assignment to departmental and/or campus-wide committees.

Involvement in professional organizations was also evidently important to the women that participated in this study. Despite their busy schedules, the majority of the respondents have held leadership positions with the Association of College Unions International, at both the regional and international levels. Their roles have included membership on conference committees, regional coordinator positions and they have also served as facilitators or presenters at both regional and international ACUI conferences. They looked upon their involvement as another way to connect with students and young professionals 
and allow for informal mentoring to take place. Their leadership roles with ACUI also increased their level of visibility within the organization and the professional arena and enhanced the overall credibility of university union directors in academia.

Summary

Although some of the women in this study alluded to on-the-job discrimination, the precise nature of this discrimination was difficult to pin down. Over all, it appears as if the women have developed the sort of support systems that helped them cope with whatever discrimination - or whatever other problem - arises, and it was clear that all the women find their jobs satisfying and fulfilling. Whether this thinking is different from the thinking of male union directors - and if it is, whether it contributes to a gender-based source of frustration with the job - could not be determined by this study.

\section{Effect of Career on Personal Life}

The data collected indicate that women who choose a career path as a university union director may face a variety of challenges in their ability to balance their vocation with their personal lives. The union directors interviewed in this study typically work ten to twelve hours a day and fifty hours a week, leaving little time to devote to their families, outside community organizations and/or hobbies and interests.

Four of the women included in the sample for this study identified themselves as married through their responses on the participant profile. Three of the respondents described their relationship status as single. Two of the 
participants selected the "intimate partner" designator to indicate their current relationship status.

Four of the female participants have children (three have more than one child). Five of the participants do not have children. Three of the women with children are all in dual-income, "traditional" families. They credited their spouses with enabling them to maintain the extended schedules that their careers as union directors often demand. The relationship status and the inclusion of children in the lives of the respondents has been charted in Table 3.

Table 3

Comparison of Relationship/Family Indicators

\begin{tabular}{|l|l|l|l|l|l|l|l|l|l|}
\hline & Ann & Barbara & Carol & Donna & Ellen & Faith & Gwen & Helen & Iris \\
\hline $\begin{array}{l}\text { Personal } \\
\text { Relationship } \\
\text { Status }\end{array}$ & Single & Married & Single & Married & Married & Single & Married & Partner & Partner \\
\hline Children & No & Yes $^{*}$ & No & Yes $^{*}$ & Yes & No & Yes & No & No \\
\hline
\end{tabular}

*More than one child

All of the women with children described incidents in which their offspring accompanied them to work. The respondents' recollections were entirely positive and indicated that their children were able to better understand their mothers' work experiences and enjoyed spending time at their worksites. In fact, their ability to spend time on a college campus during their formative years could influence their decision to attend college and increase the possibility that these children would be more involved as students. None of the respondents indicated that they received a negative reaction from their 
supervisors or staff members for bringing their children to work with them or that the presence of their kids impacted their ability to perform their jobs.

The more common pattern for the majority of the respondents was to remain single and childless. This finding is significant as it corresponds to recent studies that indicate that women in academia actually delay or put off having families because they feel pressured to teach and publish in order to be granted tenure (in the case of female faculty members) or work the irregular hours and extended work schedules associated with the union management field (Anyaso, 2002; Hamilton, 2003).

Balance was equally important to the respondents without children. They all described interests or hobbies that they pursued when they were away from their respective campuses, including travel, golf, reading and spending time with family and friends.

Thus, all the women in this study indicated both that they managed to find some balance between the demands of a demanding job and the need for a personal life. Some interviewees seem to do this balancing act better than others, and it may be significant that the majority of the women in the study were not married and remained childless. It certainly is worth speculation about how the demands of the job influence the attractiveness of the job to women, especially women who want to be married and have children. It is possible that the demands of the job issue may be a fourth factor that helps explain the limited number of women in union director positions. 


\section{$\underline{\text { Summary }}$}

The findings for this study have been presented as both individual case studies and as the results of a cross case analysis. The case studies allowed for an increased understanding of each of the nine participant's daily responsibilities, leadership styles and the impact of career choice on their personal lives. The cross case analysis resulted in a collective sense of the similarities and distinct variations of the participants' ability to obtain their directorship positions, the perceived impact that gender has played on their ability to succeed in the field and the strategies they have utilized to mesh their careers as union directors with their personal lives. The following chapter will present a discussion of these findings and how they respond to the study's research questions as well as ideas for future research related to women in the field of union management and higher education administration in general. 


\section{CHAPTER FIVE}

\section{DISCUSSION}

This study focused on women who have been successful in what traditionally has been a man's world. More specifically, this project examined the perceptions and experiences of nine women who currently hold or have held the position of director or executive director of a college or university union facility. Written participant profiles completed by each of the participants and oral interviews conducted by the researcher yielded a wide array of observations and insights related to the ability of women to obtain union directorships, the perceived impact of their gender on their ability to succeed in the field and the ability of these women to successfully balance their careers as union directors with their personal lives.

This chapter provides an integrative view of the study's primary findings as well as a critical assessment of the implications and limitations of the research. Finally, this chapter also offers suggestions for future research related to this particular population and the field of university union management.

The Effect of Gender on the Ability to Obtain a Directorship

According to the respondent's perceptions, direct gender discrimination had little, if any, effect on their ability to obtain a 
directorship position within the field of university union management. However, a variety of external and internal factors - some of which may have been associated with the variable of gender - appeared to have a greater impact on the ability of these women to obtain such jobs. Examples included the pattern of longevity established by white male university union directors that limited the number of available positions, the lack of practical experience related to facilities management and operations that had been obtained by the women during their undergraduate and graduate programs, and their feelings of inadequacy or incompetence in comparison to other candidates.

As a result of the limited number of available union directorships, women seeking middle management positions in student affairs and/or university union settings tend to find themselves in programming positions (director of student activities, associate director of programs, program director or program advisor). Women have also traditionally been relegated to positions that have been more nurturing or clerical in nature, including day care manager, scheduling and reservation manager and information/ticket manager (ACUI, 2003). The "glass ceiling" that has been described by some of the respondents may be more of a reality for some women than others, especially those that lack mobility or are unwilling to relocate for more advanced career opportunities.

The participants' responses indicated that the majority of the women included in the sample felt that they lacked the operational and technical skills typically associated with union directorships when they initially obtained their positions. Although the undergraduate and graduate programs completed by the majority of the respondents had prepared them for the leadership and managerial aspects of middle management jobs, their educational experiences 
lacked coursework and/or practicum requirements specific to the field of university union management. As a result, the female directors that participated in this study relied upon on-the-job experiential learning, involvement in professional organizations and attendance at conferences, seminars and workshops to provide them with supplemental information and training specific to their roles as union directors.

Many of the responsibilities associated with union directorships are also unique to the individual union facilities and the campuses they are located on. Novice directors may need to familiarize themselves with the political climate of their respective campuses and experience the annual cycle of events, programs, projects and services that are frequently engrained in a union's history before they can introduce any new ideas or visions for future change or growth.

Now, it may well be the case that males also often lack certain technical knowledge required to succeed in the field of university union management and they most certainly often may not understand the unique features of a particular situation or environment before on-the-job learning occurs. Men, however, may be socialized in ways that lead them to have fewer self-doubts about their ability to learn on-the-job. To the extent that gender factors played out in the cases studied here, it may have been in this subtle area of socialization and internalized self-images.

The three women of color included in the study's research sample felt that their ethnicity had a greater impact on their ability to obtain a union directorship than their gender. Somewhat ironically, all three expressed concern that, now that they attained a union director position, members of their campus communities and/or colleagues might credit their appointment to their 
respective positions as an attempt to meet affirmative action requirements or fill quotas, rather than being based upon their experiences and qualifications. These women found that it was difficult to distinguish between incidents of sexism and incidents of racism that they had experienced during their individual working lifetimes.

\section{The Impact of Gender on the Ability to Succeed in the Field}

While the women included in this study may not have felt that their gender had impacted their ability to obtain a directorship position, their responses clearly indicated that they believe their gender had an effect on their ability to succeed in the field. Particularly significant were incidents of disrespect by male colleagues and the pressure felt by female directors to gain and demonstrate competency in areas that were considered the domain of males (i.e., construction and renovation, fiscal management, operations and maintenance).

The majority of the participants recalled situations in which they were ignored at meetings, felt that their knowledge or ideas were being questioned or dismissed, or were excluded, because of their gender, from out-of-office experiences where business-related issues were discussed and decisions were made (e.g. golf outings, happy hours, etc.). The respondents also suggested that they felt compelled to work harder in an effort to prove to their supervisors and co-workers that they were truly worthy of their positions. Two of the women who had relocated to new campuses for their current directorships found that 
they needed to re-establish their credibility despite their previous work histories, educational credentials and professional reputations in the field.

In part because of the perceived need to continually prove themselves worthy of their jobs, all of the subjects noted that they were willing to address their respective professional weaknesses and made continuous efforts to add to their knowledge and understanding of information that was relevant to their positions. Their learning strategies included attending seminars, conferences and workshops, utilizing discipline-related listserves, networking with other directors that may have shared similar experiences or circumstances and simply asking questions during meetings when additional insight was needed. Not all of these activities were always motivated by the perceived need to continually prove their worth because of their gender of course, but undoubtedly this was part of the motivation. All of the women also discussed their willingness to work long hours, attend countless meetings and programs and serve as advocates for students and their needs on various campus-wide committees. Whether they worked longer and harder than their male counterparts could not be determined in this study, of course.

The participants' responses indicated that the impact of gender was not always negative. A number of them noted that they had dedicated themselves to this profession and actively modeled the basic tenets of the university union philosophy: fostering a sense of community, offering quality programs, activities, services and facilities and educating students in leadership, social responsibility and values (www.acuiweb.org/public/about/role.asp). Despite the political undercurrents typically found on college and university campuses and their impact on most union directorship positions, all of the women clearly 
enjoyed the multifaceted aspects of their work and did not express regret over their decision to pursue a directorship or remain in the field of union management.

\section{Impact on Personal Life}

The data collected from the participant profiles and oral interviews suggested that the female union directors' decision to pursue a career in university union management has had a noticeable impact on their personal lives. While the four women included in the sample for this study that identified themselves as mothers appear to have successfully balanced their jobs and their familial responsibilities, the number of women that identified themselves as single and childless can also be seen as significant.

Three of the female directors with children were all in stable relationships and traditional family settings that included a spouse and the luxury of two incomes to assist with the costs associated with housing, transportation and child care. One woman had been widowed at a young age and began to work in the student activities office at a local college campus to support her family. While her financial resources may have been significantly less than those of the married women in the sample, many of the strategies she employed to balance her personal and professional roles were similar to those described by the other respondents with children. For example, the single mother also brought her children to work with her and allowed her youngsters to actively participate in the programs and daily workings of her union. 
The four female directors with children indicated that having a family and a career forced them to adopt routines or incorporate structure into their daily schedules in order to provide some sense of order to their lives. These findings are consistent with those of previous studies (McKenna, 1997; Nobbe \& Manning, 1992; Swanka, 1997; Swanka, 1998) which examined the lack of flexibility and support within organizational environments that contributed to the dissatisfaction of working mothers and may have resulted in the loss of highly capable and productive employees. Recommended strategies by the participants with families included maximizing their productivity during their time at the office (i.e., "working smarter") and the use of flexible schedules and technology (conference calls, voicemail, email and fax machines) to allow women to work from home, when necessary.

One participant was fortunate enough to have her spouse serve as a "stayat-home-dad" for the first few years of their child's life. This situation was unique, however, when compared with the other women in the sample that also had families. While two of the other female directors with children shared parenting responsibilities with their husbands, it was still apparent that the women performed the majority of the tasks associated with their roles as their offspring's primary caregivers.

Union directorships require individuals to be physically present at their job sites, limiting the plausibility of working from home or telecommuting on a regular basis. The responses of the women included in this study, however, suggested that female union directors have been able to develop trusting and communicative relationships with their staff members that enabled them to limit the amount of time that they are required to spend at work. 
The responses given by the participants during their individual interview sessions suggested that female union directors were able to establish boundaries between their personal and professional lives, regardless of their relationship or family status. One of the respondents, for example, refused to have an internet connection at home and instead, relied on the phone and voicemail to communicate with her staff members during off-hours or in the event of an emergency. The majority of the participants indicated that they preferred to stay at work and complete time-sensitive projects or tasks, rather than take them home as "homework."

All of the women included in this study recognized the importance of balancing their personal and professional lives. Hobbies such as travel, golf, gardening and reading and volunteer service to local community agencies were all given as examples of activities that these women explored in an effort to separate themselves from their professional roles.

Finally, the data collected suggested that each of the participants had their own personal concept of success and what success meant for them. For some of the women, it appeared that their image of success included their role as a union director, a home, spouse and children. Others apparently viewed success as their achievement of a union directorship, holding a leadership position in a professional or community-based organization, their decision to pursue a terminal degree and / or the creation of new programs and facilities on their respective campuses.

While the majority of the women interviewed appeared content or satisfied with their current positions, two of the women included in the sample hoped to use their directorships as stepping stones to upper level administrative 
positions within student affairs. One of these women was already an applicant for an associate vice president opening at her current institution. The other woman had been encouraged to apply for a similar opportunity at her campus, but wanted to enroll in a doctoral program prior to considering another role in higher education administration.

The variances in the perceptions of success by the nine women featured in this study caused the researcher to question the existence of a "glass ceiling" within the field of university union management. Does a "glass ceiling" actually exist, or are the majority of these women unwilling to accept the additional challenges that an upper level administrative position might pose (such as additional hours, travel, possible geographic relocation and the requirement to learn new skills or competencies)?

\section{$\underline{\text { Suggestions for Future Research }}$}

A longitudinal study of the participants included in this project is easily warranted to determine how many of the subjects remain in the field, are still at their current institutions, have continued to advance in the field of higher education administration or have left the field entirely over the next decade or more.

As the sample created for this study contained women that were all employed at large, public institutions, this study could also be repeated with female union directors at small, private institutions, for comparative purposes. The resulting data could provide answers to questions related to the discrepancy 
in salaries and the overall scope of responsibilities assumed by women in directorship roles.

The sample utilized for this study could also be compared to other divisions within student affairs where middle management positions are dominated by women (i.e., student activities). Do women in middle management positions in other divisions of student affairs experience any or all of the challenges faced by women in union directorship positions (inability to establish collegial relationships with male colleagues, feelings of inadequacy or incompetence, varied perceptions of opportunities for advancement in the field, inequity in pay, etc.)?

Additional research also is necessary to continue to explore the overall progress of women in the field of university union management. Will more women enter the field as a result of the retirement of long-term male union directors? Studies to answer this question could be conducted in five-year increments to track changes over an extended period of time.

While the sample for this study contained three women of color, it is also important to continue to investigate the entry of underrepresented populations into union directorship positions. How might their experiences differ from male colleagues of color and/or Caucasian men and women?

Finally, it is important to examine the continued success and achievement of women that currently serve as directors of union facilities on college and university campuses throughout the United States. It will be particularly interesting to determine if female union directors establish the patterns of longevity in their positions similar to those of their male predecessors. Or, will 
union directorships finally be viewed as an appropriate segue-way to a vice presidential or presidential post?

\section{Recommendations}

Clearly, there is still work to be done in the field of university union management to attract women to directorship positions and provide them with training and resources that will help to ensure their success. For instance, the idea of regional and national workshops related to women in union management still need to be developed and offered by professional organizations such as ACUI, NASPA and NACA to encourage young female professionals to consider a union directorship as part of a career path in higher education administration. Additional educational sessions are also essential to better prepare women for work in operations and facilities management positions. The issue of affordable, on-site child care at conferences and seminars also needs to be addressed to enable more women to attend professional development opportunities and still maintain that sense of balance in their lives.

Since personnel issues appeared to be the crises that affected the women in this study the most, supplemental training in conflict management/resolution and human resources management is also suggested. Additional preparation in these areas would hopefully alleviate some of the feelings of anxiety that female directors have described when they have been required to discipline or terminate employees with whom they had close personal relationships. 


\section{Reflections on the Research Process}

Now that this project has ended, it is easy to look back and think about alternate approaches that could have been taken. For example, the findings for this study would probably have been significantly different if employees and students associated with each of the subjects had been interviewed as well. This additional means of data collection would have helped to ensure the credibility of the participant's responses to the various questions asked during the oral interviews, particularly those related to leadership/managerial styles, crises management and their ability to balance their professional and personal lives.

Findings may also have been affected if the subjects have been observed in their respective work environments. Because the interviews were conducted during various ACUI annual conferences, the goddesses included in the sample were removed from their natural settings (i.e., their respective unions). Again, this increased the probability that their responses might be more subjective or introspective that anticipated. It is believed, however, that the professional reputations of the subjects and the researcher's existing knowledge related to university unions limited the need for site visits to be included in the methodology of this study.

The fact that all of the women included in the sample were employed at large, four-year, public institutions was entirely coincidental. And, while the data they contributed to this study was significant and indicated that women are capable of serving as directors of some of the largest, high-profile union facilities in the United States, it was difficult to fully determine what inequities continued to exist for women in this field (pay, hours, treatment, etc.) because the working 
environments of all of the subjects were so similar. Due to this limitation, the selection and inclusion of female directors from small, rural campuses in the research sample would have been valuable to this study for comparative purposes.

\section{Conclusion}

As the twenty-first century continues, it is inevitable that more women will continue to go into professional fields that have previously been dominated by men. The field of university union management is no exception. This study has attempted to explore the ability of women to obtain directorship positions in college or university union environments. It is my hope that the insights of the respondents as well as my analysis of those insights will contribute to a better understanding of the common experiences and dilemmas faced by individuals in directorship positions. It is also hoped that the challenges specific to women in these positions will be better understood and that supervisory and/or policy changes will encourage more women to enter the field.

In his examination of leadership effectiveness in the field of university union management, Zarr (1992) noted, "The great unions of yesterday, today and tomorrow are those unions that have innovative, dynamic leadership" (p. 88). Like the Greek and Roman goddesses that paved the way for their followers through their embodiment of wisdom, caring and success, the goddesses included in this study have demonstrated their ability to provide the vision, intellect and guidance to take their respective facilities into the future. In addition, the women (and men) who follow in their footsteps can benefit from 
their wisdom and learn from their struggles, as well as from their accomplishments. 


\section{REFERENCES}

ACUI membership directory \& sourcebook, 1999-2000. (1999). Bloomington, Indiana: Association of College Unions International.

ACUI membership directory \& sourcebook, 2001-2002. (2001). Bloomington, Indiana: Association of College Unions International.

Anyaso, H. H. (2002). When a good thing comes along. Black Issues in Higher Education. 19, (20) 4.

Association of College Unions International. (1998). Average salary increase rises for fifth straight year. The Bulletin, 66, 29-31.

Association of College Unions International (2003). 2002-2003 salary survey. The Bulletin, 71, 24-27.

Association of College Unions International. (1988). College unions: Fifty facts. Bloomington, IN: Author.

Astin, H. S. \& Leland, C. (1991). Women of influence, women of vision: a cross-generational study of leaders and social change. San Francisco: Jossey-Bass.

Beachem, L. H. (1993). Dialogue: The road to becoming a union director isn't always a straight path. The Bulletin, 61, 16 .

Belenky, M. F., Clinchy, B. M., Goldberger, N. R. \& Tarule, J. M. (1986). Women's ways of knowing. New York: Basic Books, Inc.

Berry, C. A. (1989). The beginnings. In A. McMillan \& N. T. Davis (Eds.), College Unions, seventy-five years. (pp. 6-11). Bloomington, Indiana: Association of College Unions International. 
Blackhurst, A. \& Hubbard, J. (1997). The new scholarship on women: Progress toward an inclusive curriculum in student affairs preparation programs. Journal of College Student Development,_38, 4533-460.

Blackhurst, A. E., Brandt, J. E. \& Kalinowski, J. (1998). Effects of career development on the organizational commitment and life satisfaction of women student affairs administrators. NASPA Journal, 36, 19-34.

Blackhurst, A. E. (2000). Career satisfaction and perceptions of sex discrimination among women student affairs professionals. NASPA Journal, 37, 399413.

Blackhurst, A. E. (2000). Effects of mentoring on the employment experiences and career satisfaction of women student affairs administrators. NASPA Journal, 37, 573-586.

Blaisure, K. R. \& Allen, K. R. (1995). Feminists and the ideology and practice of marital equality. Journal of Marriage and Family. 57, (1) 5-19.

Bogdan, R. C. \& Bilken, S. K. (1998). Qualitative research for education: an introduction to theory and methods. ( $3^{\text {rd }}$ ed.). Needham Heights, Massachusetts: Allyn \& Bacon.

Bolen, J. S. (1984). The goddess in every woman. New York: Harper \& Row.

Bolton, M. K. (2000). The third shift: Managing hard choices in our careers, homes, and lives as women. San Francisco: Jossey-Bass.

Brockway, L. S. (2002). A goddess is a girl's best friend. New York: The Berkley Publishing Group. 
Burke, J. R. (1997). Examining the validity structure of qualitative research. Education. 1118, (2) 282-292.

Burns, M. (1982). Who leaves the student affairs field? NASPA Journal, 20, 912.

Butts, P. (1971). The union idea. Bloomington, Indiana: Association of College Unions-International.

Carlson, J. M. (1989). The '20's. In A. McMillan \& N. T. Davis (Eds.), College unions, seventy-five years. (pp. 12-19). Bloomington, Indiana: Association of College Unions International.

Chliwniak, L. (1997). Higher education leadership: Analyzing the gender gap. ASHE-ERIC Higher Education Report: Vol. 25, No. 4. Washington, D. C.: The George Washington University, Graduate School of Education and Human Development.

Clark, M. C., Carafella, R. S. \& Ingram, P. B. (Spring, 1998). Leadership at the glass ceiling: Women's experience of mid-management roles. Initiatives, 58, (4) 59-70.

Clark, M. C., Carafella, R. S. \& Ingram, P. B. (Spring 1999). Women in leadership: Living with the constraints of the glass ceiling. Initiatives, 59, (1) 65-75.

Clay, G. \& McMillan, A. (1974). A study of the status of women in the union field and their attitudes. Proceedings of the fifty-fourth annual conference of the Association of College Unions-International, 172-260.

Creswell, J. W. \& Miller, D. Determining Validity in Qualitative Inquiry. Theory Into Practice. 39, (3) 124-130.

Crisp, W. R. (1997). Women + power $=$ suspicion. Executive Female, 20, (1) 80. 
Dailey, D. (2002). A harrowing experience: Finding common ground between feminism and student development. In N. Davis Metz \& C. Sievers (Eds.), Student leadership in college unions and student activities (pp. 67-72). Bloomington, Indiana: Association of College Unions International.

Delahunty, T. (1986). Survey on the status of women. Unpublished manuscript. Associations of College Unions International.

Donmoyer, R. (1990). Generalizability and the single-case study. In E. W. Eisner \& A. Peshkin (Eds.), Qualitative inquiry in education: The continuing debate. New York: Teachers College.

Drake, J. (1997). Third wave feminisms. Feminist Studies, 23, 97-108.

Earwood-Smith, G., Jordan-Cox, C. A., Hudson, G. and Smith, M. U. (1990). Women making it to the top as chief student affairs officers. NASPA Journal, 27, 299305.

Eisler, R. (1989). The chalice and the blade. New York: Harper \& Row.

Este, D., Sieppert, J. \& Barsky, A. (1998). Teaching and learning qualitative research with and without qualitative data analysis software. Journal of Research on Computing in Education, 31 (2) 138-154.

Evans, N. (1988). Practicing what we teach: Implications of the new scholarship on women for student affairs preparation. Journal of College Student Development, 29, 499-501.

Fagan, A. F. (1996). The college union: The living room of the campus. In N. D. Metz (Ed.), Student development in college unions and student activities (pp. 39-42). Bloomington, Indiana: Association of College Unions International. 
Findlen, B. (Ed.). (1995). Listen up: voices from the next generation. Seattle, Washington: Seal Press.

Fox, M. F. (1989). Women and higher education: Gender differences in the status of students and scholars. In J. Freeman (Ed.), Women: a feminist perspective. (pp. 217-235). Mountain View, California: Mayfield Publishing Company.

Frankel, R. M. \& Devers, K. J. (2000a). Study design in qualitative research -1 : Developing questions and assessing resource needs. Education for Health: Change in Learning and Practice, 13, (2) 113-123.

Frankel, R. M. \& Devers, K. J. (2000b). Study design in qualitative research -2 : Sampling and data collection strategies. Education for Health: Change in Learning and Practice. 13, (2) 263-271.

Freeman, J. (1989). Women: a feminist perspective. Mountain View, California: Mayfield Publishing Company.

Glesne, C. (1999). Becoming qualitative researchers: an introduction. $\left(^{\text {nd }} \mathrm{ed}.\right)$. New York: Addison Wesley Longman.

Golde, C. \& Blank, K. (2002). Programming leadership skills for women. In N. Davis Metz \& C. Sievers (Eds.), Student leadership in college unions and student activities (pp 73-77). Bloomington, Indiana: Association of College Unions International.

Greenwood-Audant, L. M. (1989). The internalization of powerlessness: A case study of the displaced homemaker. In J. Freeman (Ed.), Women: A feminist perspective. (pp. 245-264). Mountain View, California: Mayfield Publishing Company. 
Hamilton, K. (2002). Do babies matter when charting an academic career? Black Issues in Higher Education, 19, (3) 42-44.

Hammond, D. (1997). Successful unions nurture their most precious assets: Their staffs. The Bulletin $, 65,12-13$.

Heifetz, R. A. (1994). Leadership without easy answers. Cambridge, Massachusetts: Belknap Press.

Holliday, G. \& Marshall, P. (1987). Women in administration: A chilly climate. Our Town: 1987 ACU-I Proceedings, 96-98.

House, P. B. (2001). Women in higher education administration: A synthesis of the literature, 1970 to 1999 (Doctoral dissertation, Seton Hall University, 2001). Dissertation Abstracts International, 62, 485.

http://www.imu.indiana.edu/about the imu/history.html

http://www.stanford.edu/home/welcome/campus/oldunion.html

http://www.umich.edu/ munion/

Johnson, R. B. (1997). Examining the validity structure of qualitative research. Education, 118, 282-292.

Jones, S. R. \& Komives, S. R. (2001). Contemporary issues of women as senior student affairs officers. In J. Nidiffer \& C. T. Bashaw (Eds.), Women administrators in higher education: Historical and contemporary perspectives, (pp. 231-248). Albany: State University of New York Press.

Ketter, J. (1989). The '40's. In A. McMillan \& N. T. Davis (Eds.), College unions, seventy-five years. (pp. 30-39). Bloomington, Indiana: Association of College Unions International. 
Ledet, L. M. \& Tracy, B. (2000). Perceptions of women's power as a function of position within an organization. Journal of Psychology, 134, 13-20.

Levitan, T. \& Osteen, J. M. (1992). College union activities and programs. In T. E. Milani \& J. W. Johnston (Eds.), The college union in the year 2000. (pp. 11-26). San Francisco: Jossey-Bass.

Lincoln, Y. S. \& Guba, E. G. (1985). Naturalistic inquiry. Beverly Hills: Sage.

Lorber, J. (1989). Trust, loyalty and the place of women in the informal organization of work. In J. Freeman (Ed.), Women: a feminist perspective. (pp. 347354). Mountain View, California: Mayfield Publishing Company.

Lunsford, L. (1984). Chief student affairs officer: The ladder to the top. NASPA Journal, 22, 48-56.

McIntosh, P. (1985). Feeling like a fraud. Work in Progress No. 18. Wellesley, Massachusetts: Stone Center for Working Paper Series.

McIntosh, P. (1989). Feeling like a fraud: Part two. Work in Progress No. 37. Wellesley, Massachusetts: Stone Center for Working Paper Series.

McKenna, E. P. (1997). When work doesn't work anymore: Women, work \& identity. New York: Dell Publishing.

Mercer, J. (1990). Student union management still an uphill battle for women. Black Issues in Higher Education, 7 (19), 18-19.

Miller, J. B. (1986). Toward a new psychology of women. ( $2^{\text {nd }}$ ed.). Boston: Beacon Press.

Mitchell, R. (1999). Ringo, the Packers, 0007 and me. The Bulletin $n_{1} 67,7-8$. 
Moore, L., Delahunty, T., Devaney, A. \& Turner, N. (1991). Who's that girl in the hardhat? Northwest Passage: Portland 1990, ACU-I Proceedings, 62-67.

Morton, C. (2003). What do we need to know? Competencies for union administrators. The Bulletin, 71, 45-49.

Morton, C. M. (1999). Knowledge and skills required for college union executive directors at research and doctoral 1 universities in the next decade. Unpublished doctoral dissertation, Virginia Tech, Blacksburg,, Virginia.

Nidiffer J. \& Bashaw, C. T. (2001). Quiet inspiration and hard work: The impact of women administrators. In J. Nidder \& C. T. Bashaw (Eds.), Women administrators in higher education: Historical and contemporary perspectives (pp. 2-10). Albany: State University of New York Press.

Nidiffer, J. (2001). New leadership for a new century: Women's contribution to leadership in higher education. In J. Nidder \& C. T. Bashaw (Eds.), Women administrators in higher education: Historical and contemporary perspectives (pp. 101121). Albany: State University of New York Press.

Nobbe, J. and Manning, S. (1997). Issues for women in student affairs with children. NASPA Journal, 34, 101-111.

Orr, C. M. (1997) Charting the currents of the third wave. Hypatta, 12, 29-45.

Padulo, M. K. B. (2001). The balancing act: Work environment issues for women with children in student affairs. Unpublished doctoral dissertation, University of San Diego, San Diego, California.

Parent, D. (1994). Profiles of our profession. The Bulletin, 62, 4-7.

Parent, D. (1993). Profiles of our profession. The Bulletin, 61, 11-14. 
Patton, M. Q. (1990). Qualitative evaluation and research methods. ( $2^{\text {nd }} \mathrm{ed}$.). Newbury Park, California: Sage.

Paynter, J. (1997). Perseverance, sense of humor help staff cope with flooding. The Bulletin, 65, 8-11.

Peshkin, A. (1988). In search of subjectivity-one's own. Educational Researcher, 17, 17-21.

Ratcliff, G. (1998). Study shows value of unions to learning. The Bulletin 65 , 28.

Ratcliffe, G. (1998). Association assessment highlights trends, concerns. The Bulletin, 66, 20-25.

Rubin, H. J., \& Rubin, I. S. (Eds.). (1995). Qualitative interviewing: The art of hearing data. Thousand Oaks, California: Sage.

Savage, K. (1992). Women and college unions: Present and future. University of the College Union: 1991 ACUI-I Proceedings, 34-35.

Schaef, A. W. (1992). Women's reality: an emerging female system in a white male society. ( $3^{\text {rd }}$ ed.). Boulder, Colorado: Wilson-Schaef.

Schum, R. N. (1995). Pay increases improve slightly following three years of decline. The Bulletin, 62, 15-17.

Shindell, W. \& Pirelli, K. (1995). Presidential panel: Role of the college union and campus activities in building community. Proceedings of the Associations of College Unions International, $75^{\text {th }}$ Annual Conference, 6-12.

Shindell, W. \& Pirelli, K. (1995). College unions, activities influence quality of campus life, community. The Bulletin, 63, 9-14. 
Snee, E. M. (1994). Split vision: Psychological dimensions of authority for women (workplace relationships). (Doctoral dissertation, Harvard University, 1994). Dissertation Abstracts International, 55, 3039.

Stewart, P. (2002). Responding to the voice of black women. Black Issues in Higher Education. 19, 24-31.

Strachan, J. (1999). Feminist educational leadership: Locating the concepts in practice. Gender \& Education, 11, 309-323.

Street, S. and Kimmel, E. (1999). Gender role preferences and perceptions of university administrators. NASPA Journal, 36, 222-239.

Swanka, G. E. (1998). Women relish challenges of being union directors. The Bulletin, 66, 10-18.

Swanka, G. E. (1997). Career paths of women directors of American college and university unions (Doctoral dissertation, Bowling Green State University, 1997). Dissertation Abstracts International 59, 0047.

Taylor, E. W., Beck, J. \& Ainsworth, E. (2001). Publishing qualitative adult education research: A peer review perspective. Studies in the Education of Adults. 33, (2) $163-179$.

Twale, D. and Jelinek, S. (1996). Protégés and mentors: Mentoring experiences of women student affairs professionals. NASPA Journal, 33, 203-217.

www.workforce.com

Walker, R. (Ed.). (1995). To be real: telling the truth and changing the face of feminism. New York: Anchor Books.

Walker, R. (1996). Changing the face of feminism. Essence, 26 (9), 123. 
Webster's new collegiate dictionary. (1975). Springfield, Massachusetts: G. \& C. Merriam Company.

Wenniger, M. D. \& Conroy, M. H. (Eds.). (2001). Gender equity or bust: on the road to campus leadership with women in higher education. San Francisco: Jossey-Bass.

Wilson, M. E. (2000). Connection and transition: Influences of career mobility on the close personal friendships of women student affairs professionals. Journal of College Student Development, 41, 529-543.

Wolcott, H. F. (1990). Writing up qualitative research. Newbury Park, California: Sage.

Zarr, J. (1992). Leadership effectiveness. Look to Atlanta: 1992 ACUI Proceedings, 88. 


\section{APPENDIX}




\author{
Appendix A \\ University of San Diego, School of Education
}

\title{
CONSENT FORM
}

Susan Payment, a doctoral student in the School of Education at the University of San Diego, is conducting an ethnographic interview as part of the research phase of her dissertation project.

1. The interview will serve as a study of women employed in the field of university union management. The purpose of this research is to gain further insight into the experiences of female union directors and the impact of their gender on their work with colleagues and students.

2. No expected risk is anticipated other than mild fatigue related to my participation in the interview process.

3. The interview will be audiotaped and transcribed for analysis; the tapes and notes will be destroyed after five years. I understand that my identity will remain confidential. I also understand that I will be given transcripts of the audiotape to review and edit, upon request.

4. I can benefit from the opportunity to talk about my experience as a university union director and what I have learned through my work in the field.

5. My participation in this study is entirely voluntary and I understand I may refuse to participate or withdraw at any time without penalty. There are no expenses associated with this study which I must incur.

6. Susan Payment has explained the research project to me and answered my questions. I understand that if I have further questions, I may contact Susan Payment at any time at (619) 260-4590 or (619) 586-1504. I may also contact Ms. Payment's dissertation chair, Dr. Robert Donmoyer, at the University of San Diego at (619) 260-7445.

7. There are no other agreements, written or verbal, related to this study beyond that expressed in this consent form.

8. I understand that I will participate in one sixty-minute interview. The data collection will take no more than one initial scheduled meeting. Follow-up interviews may be scheduled in the future to obtain additional data and clarify details obtained during the initial interview.

9. My identity will be will remain confidential and I will be assigned a pseudonym in the transcription of the interview.

I, the undersigned, understand the above explanations and on that basis, consent to voluntary participation in this research.

Signature of Participant

Signature of Researcher
Date and Location

\section{Date}

Date 


\section{Appendix B \\ Women University Union Directors \\ Participant Profile}

Name:

(Last)

(First)

(Middle/Maiden)

Date of Birth:

(Month/Day/Year)

Birthplace:

(City/State/Country)

Personal Relationship Status (select one):

- Single

-Married

- Separated

-Divorced

-Widowed

-Intimate Partner

Please describe your formative years (including where you grew up, childhood hobbies/activities, etc.)

Educational Background (please list school(s) attended and degree(s) received, starting with most recent):

Employment History (please list all prior work experience, starting with your current position):

\section{Current Salary:}

Please describe the organizational structure of your current work environment:

How did you become involved in university union management? 
What do you enjoy most about your role as a union director?

What do you enjoy least about your role as a union director?

How has your career as a union director impacted your personal life?

Do you see yourself as a mentor? If so, how and for whom?

What are your views regarding gender equity for female union directors?

Thank you for your cooperation 
Appendix C

Interview Questions

1. How do you view your role as a union director?

2. Describe a typical day at your union.

3. Describe your management style

4. How do you feel that your management style differs from that of your male colleagues?

5. Have you ever felt that your gender has limited your ability to succeed in the field of university union management? If so, how?

6. What advice would you give to a young woman who intends to enter the field of university union management?

7. Do you feel that your educational background prepared you for your current position? Why or why not?

8. What are your hopes for the future for women in your field? 